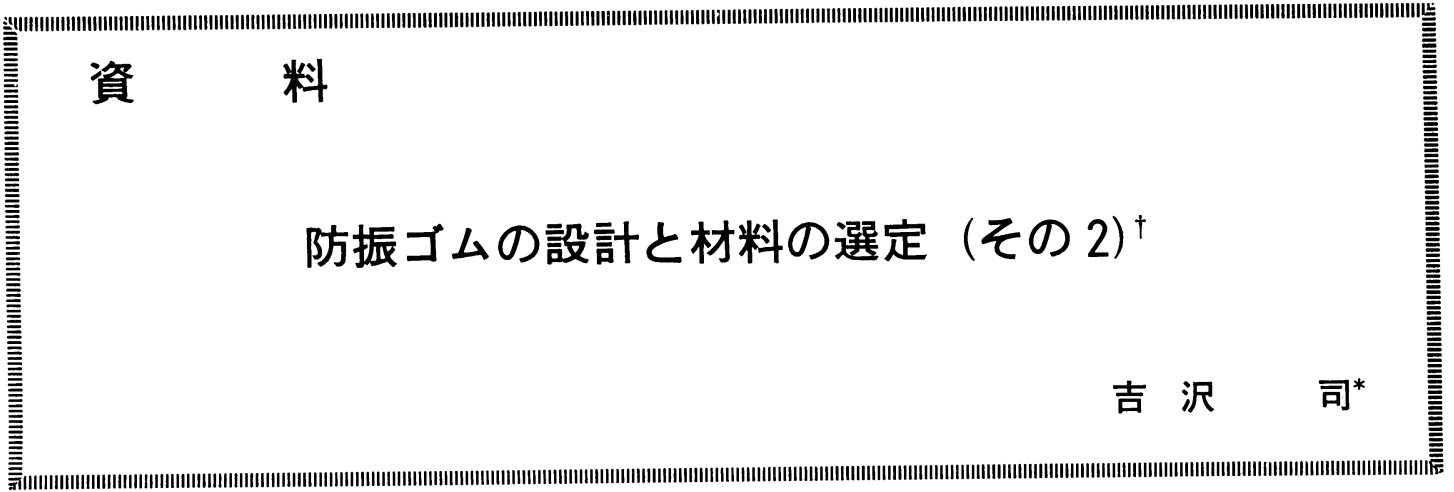

\section{5. 防振ゴム材料の動的性質}

\section{1 ゴムの動的挙動}

一般に高分子物質においては, 応力が与えられた場合 とひずみが与えられた場合とでは挙動が異なり，この理 由は一義的に定まる弾性要素とひずみの履歷に関する粘 性要素から成立っているからであると考えられている. ゴムも粘弾性体物質なるのでこれら 2 つの要素から成立 っているといえる.この弾性要素と粘性要素の組合せに ついては, 種々のモデルが考えられているが, 最も基本 的でかつ有名な Maxwell model と Voigt model の 2 つ がある. 応力が与えられた場合に対するひずみを考える には V-model を，ひずみが与えられた場合に対する応 力を考えるには M-model を対応させると便利である.

5.1 .1 応力が与えられた場合 V-model は図28に 示すご๖く, 弾性要素のスプリングと粘性要素のダッシ

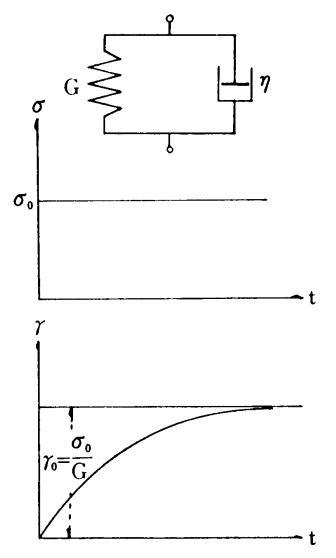

図28 Voigt-Model とクリープ

†日ゴム協誌, 49, 4〜 16 (1976)

* 鬼怒川ゴム工業侏（テ281 千葉市長沼町330)

( 31 )
ユポットとが並列に接続されているもので，この model に応力が加わると, 弾性要素はHook の法則に従い瞬間的 に弾性変形をするが, 粘性要素は応力が作用する時間に よって変化し, Newton の法則に従って流動変形をする.

弾性率を $G$, 粘性係数を $\eta$, 応力を $\sigma$, ひずみを $\gamma$ とす れば,

全 応力: $\sigma=\sigma_{1}+\sigma_{2}$

弾性要素: $\sigma_{1}=G \gamma$

粘性要素: $\sigma_{2}=\eta d \gamma / d t$

$\sigma=G \gamma+\eta d \gamma / d t$

となる. 式 (44) の微分方程式は $\gamma=u v$ とおいて解けば

$$
d \gamma / d t=u d v / d t+v d u / d t
$$

となり，式(44)に代入すれば，

$$
\sigma=G u v+\eta(u d v / d t+v d u / d t)
$$

ここで,

$$
\begin{aligned}
& u(G v+\eta d v / d t)=0 \\
& \eta v d u / d t=\sigma
\end{aligned}
$$

とおけば,

$$
v=C_{1} e^{-G t / n}
$$

式(49)を式(48)に代入して求められる.ただし $C_{1}$ は積 分常数である.

$$
u=\sigma e^{-G t / n} / G C_{1}+C_{2}
$$

したがって

$$
\gamma=u v=\sigma / G+C e^{-G t / \eta}
$$

$t=0$ のとき, $\gamma=0$ なるから積分常数 $C=-\sigma / G$ とな り,

$$
\gamma=\sigma / G \cdot\left(1-e^{-t / \lambda}\right)=\gamma_{0}\left(1-e^{-t / \lambda}\right)
$$

となる.ここで $\lambda=\eta / G$ は遅延時間と呼び, 一定応力 の下におけるひずみの時間的変化は, 式(52)で表はされ クリープといわれる. 応力を除去すると, 指数曲線にし たがって，徐々に回復する．その関数は $\gamma_{0} e^{-t / \lambda}$ で表わ されこれをクリープ回復という. 

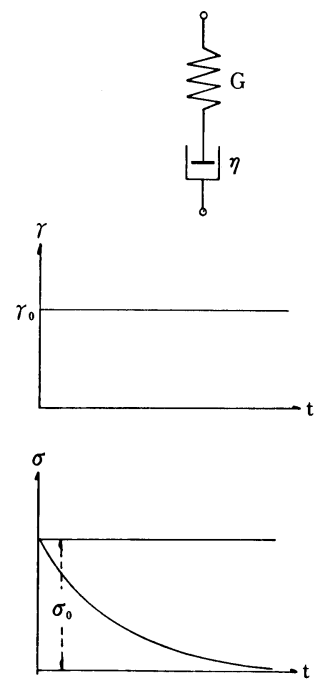

図29 Maxwell-Model と応力緩和

5.1.2 ひずみが与えられた場合Ｍ-model は図 29 に示すごとく, 弾性要素のスプリングと粘性要素のダッ シュポットが直列に接続されている．この model にひすず み $\gamma$ を与えると $\mathrm{V}-$ model と同様に，

全 変形: $d \gamma / d t=d \gamma_{1} / d t+d \gamma_{2} / d t$

弾性変形: $d \gamma_{1} / d t=d \sigma / G d t$

粘性流動: $d \gamma_{2} / d t=\sigma / \eta$

$d \gamma / d t=d \sigma / G d t+\sigma / \eta$

と表わされ， $\gamma$ は一定びずみなるから $d \gamma / d t=0$ となる 式(53)は,

$$
\begin{aligned}
& d \sigma / \sigma=-G d t / \eta \\
& \sigma=C e^{-G t / \eta}
\end{aligned}
$$

となる. 積分常数 $C$ は, $t=0$ のとき $\sigma=\sigma_{0}$ なるから $C=\sigma_{0}$ 上なり，従って式(54)は，

$$
\sigma=\sigma e^{-t / \tau}
$$

$\tau=\eta / G$ をその材料の緩和時間といい, 一定ひずみの下 における応力の時間的変化は式(55)で表わされる. 応力 は時閒とともに指数関数的に低下しこの現象を応力緩和 という.この式は先に述べた式(42) と等価である. 遅延 時間 $\lambda$ も緩和時閒 $\tau$ も共に材料固有のもので, $\eta / G$ で表 わし得る内部タイムスケールである. 即ち実験のタイム スケールが，この内部タイムスケールに比べて，

i ) $t<\eta / G$ : 弾性変形のみが現われ理想弾性体のよ らな挙動を示す

ii) $t=\eta / G$ : 弾性及び粘性の変形が現われ, 粘弾性 体の挙動を示す

iii） $t>\eta / G$ : 流動が優勢になって, 粘性流動体の挙

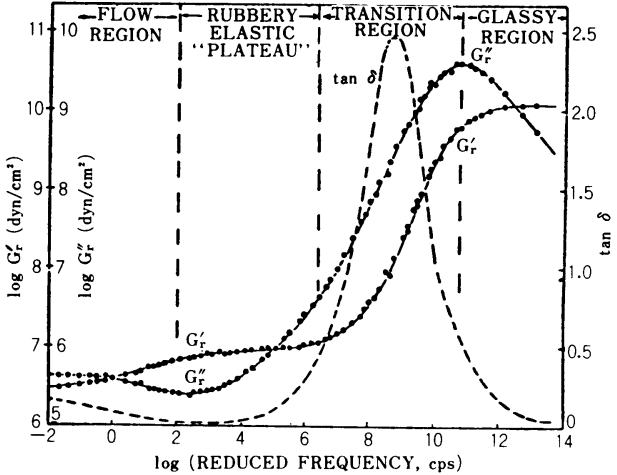

図30 周波数依存性

動を示す

図30は超低周波数領域から極超短波領域に至るまでの， ゴムの周波数依存性を示したものである．即ち周波数が 高くなると, ゴムはゴム状態から段々離れ, 結晶化し, 弾性率及び損失係数は大きく変化する．この現象は実験 タイムスケールと内部タイムスケールの関数を証明して いるといえるものである．

粘弾性体は実験タイムスケールによって, その挙動は 異なり，一般にいわれるゴムにおける静的特性と動的特 性が異なる主たる理由である。いま式(44)に $\gamma=\gamma_{0} \sin$ $\omega t$ なる正弦ひずみを与えた場合を考えてみる．この場 合通常は，複素数を導入するのが便利である．数学的に は, $e^{i x}=\cos x+i \sin x, e^{-i x}=\cos x-i \sin x$ を利用し て, $\gamma=\gamma_{0} \sin \omega t$ の代りに $\gamma=e \gamma_{0}{ }^{i \omega t}$ とおいて解き $\sin$ の場合は虚数部， $\cos の$ 場合は実数部をとれば，実変数 関数として解いた場合と全く等しくなる.したがって $d \gamma / d t=i \omega \gamma_{0} e^{t \omega t}$ となるから式 (44) は次のごとく表わし 得る.

$$
\sigma=(G+i \omega \eta) \gamma_{0} e^{i \omega t}
$$

ここで $G=G_{1} \eta \omega=G_{2}$ とおいて整理すれば,

$$
\begin{aligned}
\sigma & =\sqrt{G_{1}^{2}+G_{2}^{2}}(\cos \delta+i \sin \delta) \gamma_{0} e^{i \omega t} \\
& =\left|G^{*}\right| e^{i \delta} \gamma_{0} \epsilon^{i \omega t}=\left|G^{*}\right| \gamma_{0} e^{i(\omega t+\delta)}
\end{aligned}
$$$$
\therefore \quad \sigma=\left|G^{*}\right| \gamma_{0} \sin (\omega t+\delta)
$$

$$
\text { or } G_{1} \sqrt{1+l^{2}} \gamma_{0} \sin (\omega t+\delta)
$$

ただし， $G_{1}$ を動的弾性率， $G_{2}=\eta \omega$ を動的損失弾性率, $G^{*}=G_{1}+i G_{2}$ を複素弾性率, $\left|G^{*}\right|=\sqrt{G_{1}{ }^{2}+G_{2}{ }^{2}}$ を絶 対弾性率， $\delta$ を位相角， $G_{2} / G_{1}=l=\tan \alpha$ を損失係数 又は損失正接という. 式 (57) は $\gamma=\gamma_{0} \sin \omega t$ なるひず みに対して応力が位相角 $\delta$ だけ進んでいることを示して いる、あるいは，ひずみは応力より位相角 $\delta$ だけ遅れる ことになる.

この model に交番ひずみの代りに交番応力を与える 
場合は式(57)よりひずみの関数として求め得るから，

$$
\begin{aligned}
\gamma & =\sigma e^{-i \delta} /\left|G^{*}\right| \\
\gamma & =\left|J^{*}\right| e^{-i \delta} \sigma_{0} e^{i \omega t}=\mid J^{*} \sigma_{0} e^{i(\omega t-\delta)} \\
& =\left|J^{*}\right| \sigma_{0} \sin (\omega t-\delta)
\end{aligned}
$$

となる.ただし $J^{*}=J_{1}-i J_{2}$ を複素コンプライアンズ， $J_{1}$ を動的コンプライアンズ, $J_{2}$ を動的損失コンプライ アンズ, $\mid J^{*}=\sqrt{J_{1}{ }^{2}+J_{2}{ }^{2}}$ を絶対コンプライアンズと いう.

次に式(53)に $\sigma=\sigma \sin \omega t$ なる正弦応力を与える場合 を考えてみる. $\sigma=\sigma e^{i \omega t}$ とおけば, 式(53)は,

$$
d \gamma / d t=(1 / \eta+i \omega / G) \sigma_{0} e^{i \omega t}
$$

$t$ について積分すれば,

$$
\gamma=(1 / G-i / \eta \omega) \sigma_{0} e^{i \omega t}
$$

$J_{1}=1 / G, J_{2}=1 / \eta \omega$ とおけば,

$$
\begin{gathered}
\gamma=\sqrt{{J_{1}{ }^{2}+J_{2}{ }^{2}}^{2}(\cos \delta-i \sin \delta) \sigma_{0} e^{i \omega t}} \\
=\left|J^{*}\right| e^{i \delta} \sigma_{0} e^{i \omega t}=\left|J^{*}\right| e^{i(\omega t-\delta)} \\
\therefore \quad \gamma=\left|J^{*}\right| \sigma_{0} \sin (\omega t-\delta) \\
\quad \text { or } J_{1} \sqrt{1+l^{2}} \sigma_{0} \sin (\omega t-\rho)
\end{gathered}
$$

となる.この model に交番ひずみを与えると応力は,

$$
\begin{aligned}
\sigma & =e^{i \delta} \gamma|| J^{*} \mid \\
& =\left|G^{*}\right| e^{i \delta} \gamma_{0} e^{i \omega t}=\left|G^{*}\right| \gamma_{0} e^{i(\omega t+\delta)} \\
& =\left|G^{*}\right| \gamma_{0} \sin (\omega t+\delta)
\end{aligned}
$$

となり式(57)に等しくなる.

複素弾性率と複素コンプライアンズとの間には次のご とき関係がある。

$$
\begin{aligned}
& G^{*}=1 / J^{*} \\
& G_{1}+i G_{2}=1 /\left(J_{1}-i J_{2}\right)=\left(J_{1}+i J_{2}\right) /\left(J_{1}{ }^{2}+J_{2}{ }^{2}\right) \\
& G_{1}=J_{1} /\left(J_{1}+J_{2}\right), \quad G_{2}=J_{2} /\left(J_{1}{ }^{2}+J_{2}{ }^{2}\right) \\
& J_{1}=G_{1} /\left(G_{1}+G_{2}\right), \quad J_{2}=G_{2} /\left(G_{1}{ }^{2}+G_{2}{ }^{2}\right) \\
& l=\tan \alpha=G_{2} / G_{1}=J_{2} / J_{1}
\end{aligned}
$$

したがって粘弾性体に交番ひずみを与えると複素弾性 率が現われ，交番応力を与えると複素コンプライアンズ が現われるのである. また損失係数 $l=\tan \alpha$ が出現す るのも動的挙動の特徴であるといえるわけである.

式 (56) 及び式 (60)を緩和時間及び遅延時間を導入して 表わせば,

$$
\begin{aligned}
G^{*} & =G_{1}+i G_{2}=1 /\left(J_{1}-i J_{2}\right)=1 /(1 / G-i / \eta \omega) \\
& =1 /(1-i / \omega \tau) / G=G \omega \tau /(\omega \tau-i) \\
& =G\left\{(\omega \tau)^{2}+i \omega \tau\right\} /\left\{1+(\omega \tau)^{2}\right\}
\end{aligned}
$$

となるから，

$$
G_{1}=G(\omega \tau)^{2} /\left\{1+(\omega \tau)^{2}\right\}, \quad G_{2}=G \omega \tau /\left\{1+(\omega \tau)^{2}\right\}
$$

遅延時間については，

$$
J^{*}=J_{1}-i J_{2}=1 /\left(G_{1}+i G_{2}\right)=1 /(G+i \eta \omega)
$$

$$
\begin{aligned}
& =1 / G(1+i \omega \lambda)=(1-i \omega \lambda) /\left\{1+(\omega \hat{\lambda})^{2}\right\} \\
J_{1} & =1 / G\left\{1+(\omega \lambda)^{2}\right\}, \quad J_{2}=\omega \lambda / G\left\{1+(\omega \lambda)^{2}\right\}
\end{aligned}
$$

となる. 実際には, 内部タイムスケールの異なる無数の 変形機構が存在し, 上記のごとく唯一個ではなく分布し ている。したがって式(67)及び式(69)を分布関数として 表わせば，次のごとくなる．

$$
\begin{aligned}
& G^{*}(\omega)=\sum G_{j}\left(i m \tau_{j}\right) /\left(1+i \omega \tau_{j}\right) \\
& G^{*}(\omega)=\sum G_{j}\left(\infty \tau_{j}\right)^{2} /\left\{1+\left(\omega \tau_{j}\right)^{2}\right\} \\
& G^{*}(\omega)=\sum G_{j} \omega \tau_{j} /\left\{1+\left(\omega \tau_{j}\right)_{z}\right\} \\
& J^{*}(\omega)=\sum 1 / G_{j}\left(1+i \omega \lambda_{j}\right) \\
& J_{1}(\omega)=\sum 1 / G_{j}\left\{1+\left(\omega \lambda_{j}\right)^{2}\right\} \\
& J_{2}(\omega)=\sum \omega \lambda_{j} /\left\{1+\left(\omega \lambda_{j}\right)^{2}\right\}
\end{aligned}
$$

\section{2 ゴムの振動依存性と温度依存性}

ゴムに振動を与えると, その周波数及び振幅によって 動的特性が変化することを知ったが，これらの性質を特 に周波数依存性及び振幅依存性と呼んでいる．そのほか に温度変化によっても，ゴムの特性值は変化し図31に示 すごとく低温になると弾性率は極度に高くなり，あたか も高周波数で観測される挙動によく似た特性を示してい る.これら依存性はポリマーの種類及び配合剤によって 異なり図32は促進剤の種類による弾性率と損失係数の振 幅依存性の例である. 図33は防振ゴム汎用ポリマーとカ 一ボン含有量による振幅依存珄を示したものである. 更 に図34はカーボン種類（カーボンの粒径）の影響を調べ たものである

Payne によれば, 線型性が成立するひずみ振幅の範囲 においては，基準ひずみ振幅 $\gamma_{0}$ に対し，弾性率を $G_{0}$ と すれば, 次の関係式が成立する.

$$
G=G_{0}\left(\gamma / \gamma_{0}\right)^{-n}
$$

$n$ を材料固有の振幅依存性係数といわれる.

また関口によれば，機械周波数領域においては, 次式 の成立することが提唱されている.

$$
\begin{aligned}
k(\nu) & =k\left(\nu_{0}\right)\left\{1+m \log \left(\nu / \nu_{0}\right)\right\} \\
l(\nu) & =l\left(\nu_{0}\right)\left\{1+m^{\prime} \log \left(\nu / \nu_{0}\right)\right\}
\end{aligned}
$$

ここで $k\left(\nu_{0}\right)$ は基準とする周波数 $\nu_{0}$ の動的ばね定数で, $k(\nu)$ は任意の求めようとする周波数 $\nu$ 動的ばね定数で ある. 損失係数 $l$ についても同様で, $m$ 及び $m^{\prime}$ は, 材 料固有の周波数依存係数といわれる.

図35(a) 及び (b) は，NR，SBR，IIR の各温度における せん断ばね定数及び損失係数の変化を示したものであ る.この図と図30とを比較すると低温側における挙動と 高周波での挙動とが類似していることが解るであろう. 即ち高周波での特性は，低温で観測される特性に置換え 


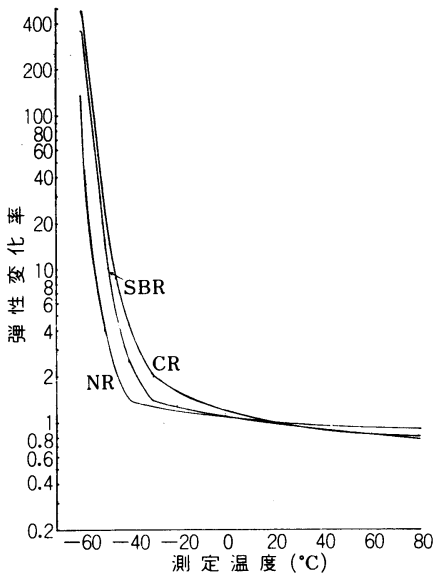

図31 各ポリマーの温度特性

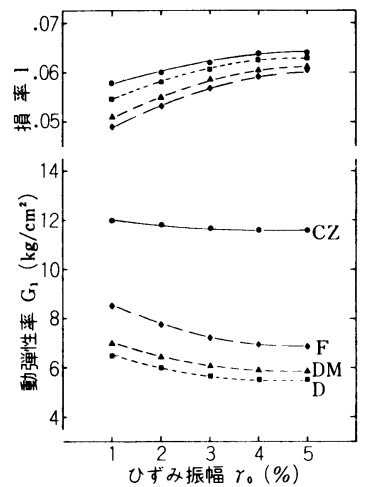

図32 促進剂種類による振幅依存性.

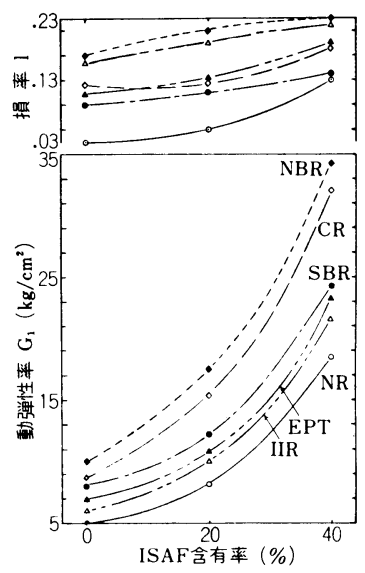

図33各ポリマーに対するカー ボン含有量の影響

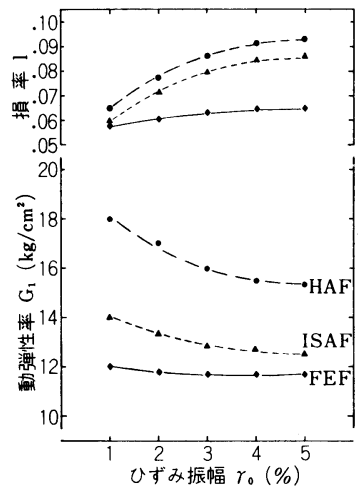

図34 カーボンの種類と振幅依存性

られるわけである．実際，実験技術上からみて，温度特 性の観測は, 適当な恒温槽があれば事足りるが, 周波数 特性の測定は簡単にはいかないのである．例えば機械振 動数から音波領域迄の実験をしようとする場合は, 用い る試料の形状を変え, 試験機能力によっては測定不可能 の場合もあり，周波数と振幅によって試験機を適当に選 定しなければならない不便さがある。したがって温度特 性によって，周波数特性が類推できることは非常に便利 である.ゴムはゴム状弾性状態を示す温度領域では, 式 (19)により弾性率 $G$ は絶対温度 $T$ に比例する．また式 (70) 及び式 (71) より $\omega \tau_{j}$ あるいは $\omega \lambda$, , 形で弾性率に 含まれていて，更にこれら緩和時間 $\tau_{j}$ および遅延時間 $\lambda_{j}$ は温度に依存する。Ferryによれば周波数と温度との 関係は次式で表わされ，

$$
\begin{aligned}
& G_{1}(\omega, T)=T_{S} \rho_{S} / T \rho \cdot G_{1}\left(a_{T} \omega, T_{S}\right) \\
& l(\omega, T)=l\left(a_{T} \omega, T_{S}\right)
\end{aligned}
$$
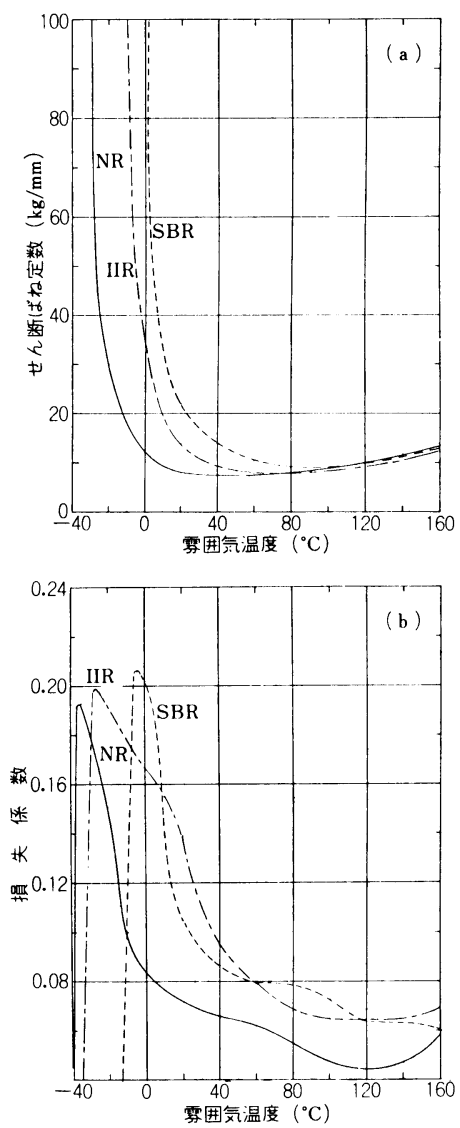

図35動的試験における各ポリマーの温度依存曲線

が成立する。この関係は多くの高分子物質について実験 されその妥当性が実証されている.ここで $T$ は実験温 
度, $T_{\mathrm{S}}$ は基準温度でいずれも絶対温度で表わす. $\rho$ 及び $\rho_{S}$ は実験温度及び基準温度に拧ける密度であるが，通 常は $\rho \fallingdotseq \rho_{S}$ としてよい， $a_{T}$ を周波数一温度換算係数又 は移動係数と呼ばれるもので, 次式で示される.

$$
\log a_{T}=-8.86\left(T-T_{S}\right) /\left(101.6+T-T_{S}\right)
$$

温度が $T_{S}$ から $T$ に変化することによって, 緩和スペク トルが $\log a_{\boldsymbol{T}}$ に相当するだけ移動するゆえに温度 $T$ に おいて周波数 レ(又は $\omega$ ) で観測される動的特性は, 温度 $T_{S}$ において $\nu_{S}=a_{T^{\nu}}$ で観測されることになる．例えば $T_{S}=250^{\circ} \mathrm{K}\left(-23^{\circ} \mathrm{C}\right)$ の NR 配合材で, $T=293^{\circ} \mathrm{K}$ $\left(20^{\circ} \mathrm{C}\right)$ でレ $=10^{4} \mathrm{~Hz}$ の動的特性を知りたい場合は, 式 (75)によって次のごとく求め得られる.

$\log a_{T}=-8.86(293-250) /(101.6+293-250)$

$$
\begin{aligned}
& =-2.6347 \quad \therefore \quad a_{T}=2.32 \times 10^{-3} \\
& =\overline{3} .3653 \quad
\end{aligned}
$$

したがって，

$$
\nu_{\mathrm{s}}=2.32 \times 10^{-3} \times 10^{4}=23.2 \mathrm{~Hz}
$$

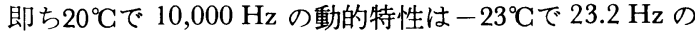
条件で測定すればよいことになる。式(76)は基準温度 $T_{S}$ を標準にしなければならないので，任意の温度を標 準にする場合は不便である。したがって次式によるのが 便利である。

$$
\begin{aligned}
\log a_{T}= & -8.86 \times 101.6\left(T-T_{0}\right) /\left\{\left(101.6+T-T_{S}\right)\right. \\
& \times\left(101.6+T_{0}-T_{S}\right)
\end{aligned}
$$

ただし， $T_{0}$ は標準温度である．基準温度 $T_{s}$ は 2 次転 移点 $T_{g}$ に対し大体次の関係があり,

$$
T_{s}=T_{g}+50
$$

さらに式 (76) 及び式 $(77)$ は $\left(T-T_{S}\right) \lesssim 50^{\circ} \mathrm{C}$ の範囲内 で成立する. 以上の方法を温度一周波数換算法則と呼ん でいる。

\section{3 ゴムの高周波における性質}

ゴムは高周波領城では，質量が無視できなくなること 上, ゴム内部の伝播速度が問題になる. 即ち波動伝播方 向のゴムの長さが,半波長の整数倍になっている時は,端 面からの反射波と干涉し発音体になる。 Credeによれ ば，ゴム内部に伝播される波動速度はゴムの損失係数と ヤング率に関係し, 次式のように表わされる.

$$
v=\sqrt{D E^{\prime} / \rho}
$$

ここで $D$ は速度係数, $E^{\prime}$ は動的ヤング率 $\left(\right.$ dyne $\left./ \mathrm{cm}^{2}\right)$, $\rho$ は比重 $\left(\mathrm{g} / \mathrm{cm}^{3}\right)$ である. 更に $D$ は損失係数 $l$ に対して 大体次のように表わし得る.

$$
D=1+3 l^{2} / 4
$$

即ち伝播速度 $v$ は，上式によりダンピングの大きい材料 の方が速いことになる。

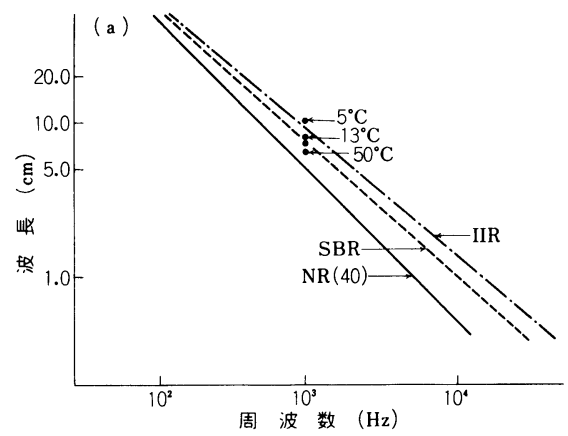

図36(a) ポリマー別ゴム内部の波長

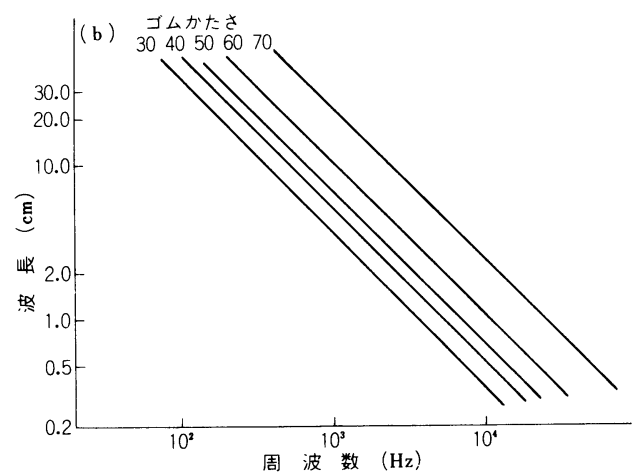

図36 (b) ゴム硬さによる内部波長の変化

NR における伝播速度の実験結果では，それぞれの值が $90 \mathrm{~m} / \mathrm{s}, 75 \mathrm{~m} / \mathrm{s}, 50 \mathrm{~m} / \mathrm{s}$ 程度である.したがって波長 $\lambda$ は $v=\lambda \nu$ より $, 9 \mathrm{~cm}, 7.5 \mathrm{~cm}, 5 \mathrm{~cm}$ となる図36(a) 及び(b) は周波数とゴム内部の波長を示したものである.

\section{4 エネルギー損失と発熱}

ゴムに周期的応力あるいはひずみを与えると，ひずみ は常に位相角 $\delta$ だけ応力より遅れ, 力学的エネルギーの 一部が熱エネルギーに変って消費され発熱をする．この 発熱はゴムの物性を変化させあるいは劣化させ, 時には ブローアウトし，耐久性には大なる影響を与える．5.1 において, 粘弾性体に応力を与えると複素コンプライ アンズが現われ，ひずみを与えると複素弾性率が現われ ることを知った. 即ち，ゴムは変形の受け方によって発 熱が異なるわけである。いま, ゴムの単位体積，1サイ クル当り消費されるエネルギーは, 粘性抵抗力によるか ら,

$$
E=\oint p \eta \cdot d \gamma=\oint \eta d \gamma \cdot d \gamma / d t=\eta \int_{0}^{2 \pi / \omega}(d \gamma / d t)^{2} d t
$$

となる．ただし $E$ は消費エネルギー, $p \eta$ は粘性力であ る。 
1）ひずみ振幅 $\gamma=\gamma \sin \omega t$ を与えた場合

$$
\begin{aligned}
E & =\eta \int_{0}^{2 \pi / \omega}\left(\gamma_{0} m \cos \omega t\right)^{2} d t=\eta \gamma_{0}^{2} \omega^{2} \int_{0}^{2 \pi / \omega} \cos \omega t d t \\
& =\eta \omega^{2} \gamma_{0}^{2} / 2 \cdot \int_{0}^{2 \pi / \omega}(\cos 2 \omega t+1) d t \\
& =\pi \eta \omega \gamma_{0}^{2}=\pi G_{2} \gamma_{0}^{2} \text { or } \pi l G_{1} \gamma_{0}^{2}
\end{aligned}
$$

となり, 消費エネルギーは損失弾性率及びひずみ振幅の 2 乗に比例する.

2）応力振巾 $\sigma=\sigma_{0} \sin \omega t$ を与えた場合

応力が与えられる場合は式(59)及び式(61)より,

$$
\gamma=\left|J^{*}\right| \sigma_{0} \sin (\omega t-\delta)=\sigma_{0} \sin (\omega t-\delta) / G_{1} \sqrt{1+l^{2}}
$$
なるから，式(81)は，

$$
\begin{aligned}
E & =\eta \int_{0}^{2 \pi / \omega}\left\{\sigma_{0} \omega \cos (\omega t+\delta) / G_{1} \sqrt{1+l^{2}}\right\}^{2} d t \\
& =\frac{\eta \omega^{2} \sigma_{0}^{2}}{2 G_{1}\left(1+l^{2}\right)} \int_{0}^{2 \pi / \omega}\{\cos 2(\omega t+\delta)+1\} d t \\
& =\pi G_{2} \sigma_{0}{ }^{2} / G_{1}\left(1+l^{2}\right) \approx \pi l \sigma_{0}{ }^{2} / G_{1}
\end{aligned}
$$

となり, 消費エネルギーは, 損失倸数及び応力振幅の 2 乗に比例し, 弾性率に反比例する. $G_{2}=\eta \omega$ 又は $l=G_{2}$ $/ G_{1}$ はエネルギー損失の度合を示す尺度になるからそれ ぞれ動的損失弾性率, 損失係数といわれるわけである. $l=\tan \delta$ は $1 / Q$ で表わし振動吸収係数と呼ばれること もある．消費エネルギー $E$ は Joul の法則により（熱の 仕事当量 $J=4.2 \times 10 \mathrm{erg} / \mathrm{cal})$ 熱量に変換される. 式 (82)及び(83)は，単位当りに対するエネルギーであるか ら, $V \mathrm{~cm}^{3}$ のゴムが周波数 $\nu \mathrm{Hz}$ で加振する場合の発熱 量 $Q$ は,

$$
Q=E V \nu / J
$$

と表わし得る。、ま体積 $V$ なるゴムが， $\tau$ から $\tau+d \tau$ 時 間に $d t$ なる温度上昇したとすれば，比重を $\rho$, 比熱を $C$ で表わせば，

$$
C V \rho d t=Q^{d}
$$

となる. 温度 $t^{\circ} \mathrm{G}$ なる物体が空間に放熱する熱 量は, Newton の冷却の法則を適用し，伝熱釈数を $\alpha$, 放熱面 積を $A$ とすれば， $d \tau$ 時間に放熱される熱量は $\alpha A t d \tau$ と なるから，

$$
\alpha C V \rho d t=Q d \tau-\alpha A t d \tau
$$

が成立する．この微分方程式を解けば，

$$
t=\frac{Q}{\alpha A}(1-e-\alpha A \tau / V C \rho)
$$

となり,

1）ひずみを与えた場合

$$
t=\frac{\pi}{\alpha J} \cdot \frac{V}{A} l G_{1} \gamma_{0}^{2}(1-e-\alpha A / V C \rho \cdot \tau)
$$

2）応力を与えた場合

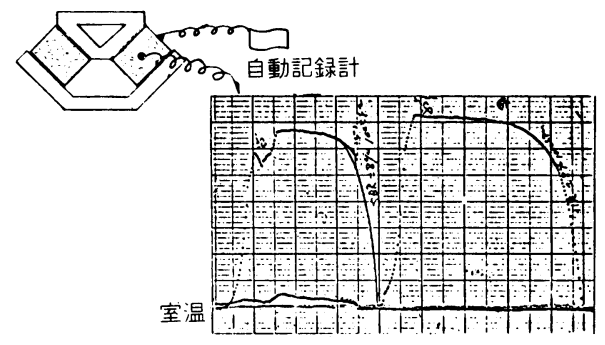

図37 発熱測定方法

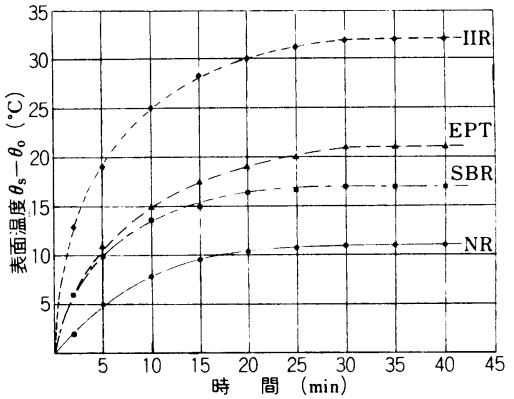

図38 $r=8 \%$ における各ボリマーの表面温度上昇 過程曲線

$$
t=\frac{\pi}{\alpha J} \cdot \frac{V}{A} \frac{l}{G_{1}} \sigma_{0}{ }^{2}(1-e-\alpha A / V C \rho \cdot \tau)
$$

となる.温度上昇は時間とともに指数関数的に上昇し， $\alpha A 2 / V C \rho$ が充分大になれば，Q/ $\alpha A$ に収斂する．したが って最高温度は $\alpha$ を求めれば, 理論的に求め得るわけで あるが， $l$ 及び $G_{1}$ は振幅及び周波数依存性により変化 し，伝熱係数 $\alpha$ は発熱体温度と周囲温度によって変化す るので正確に求めるには困難である．筆者は $40 \times 40 \times 30$ $\mathrm{mm}$ の角柱型試料について図37に示す方法で, 内部及び 表面の温度上昇を測定した．図38は， $\gamma_{0}=8 \%$ （圧縮方 向） $\nu=10 \mathrm{~Hz}$ の条件における $\mathrm{NR}, \mathrm{SBR}, \mathrm{EPT}, \mathrm{IIR} の$ 汎用防振ゴム材料の表面温度上昇過程を示したものであ る. 本実験はひずみ振幅一定で行ったため式 (88) が適 用され， $\tau=30^{\prime}$ でほぼサチレートしている．内部温度 の測定は，非常に困難な面がある。まず試料の作成であ る．通常はゴムの中央部まで穴をあけて熱電対を差込む か, あるいは加硫成形時に插入し同時成形するか, いずれ かの方法で熱電対をゴム中央まで入れねばならないこと である．試料はできたとしても加振することによって摩 擦しこの発熱の影響を受けたり，穴をあけたことによっ て破断したりするが，これに比して表面温度の測定は比 較的容易である。したがって表面温度から内部温度が推 定できたら非常に便利であり，更にある振動条件を基準 
にして, 種々の条件での発熱温度が推定できたらより便 利である。

高温の固体が空気中に放熱する場合，熱伝達率を $\alpha$, 固体表面温度を $\theta_{S}$ (表面温度一雲囲気温度), 空気の流 通速度を $v(\mathrm{~m} / \mathrm{s})$ とすれば，伝熱工学より，

$$
\begin{aligned}
\alpha & =2.2 \theta_{s^{1 / 4}} \quad\left(\mathrm{kcal} / \mathrm{m}^{2} \cdot \mathrm{hr} \cdot{ }^{\circ} \mathrm{C}\right) \\
\alpha^{\prime} & =\alpha \sqrt{1+v / 0.348}
\end{aligned}
$$

で表わされ，G·G·S·unit で表わせば，

$$
\begin{aligned}
& \alpha=6.111 \times 10^{-5} \theta_{\mathrm{S}}^{1 / 4} \quad\left(\mathrm{cal} / \mathrm{cm}^{2} \cdot \mathrm{s} \cdot{ }^{\circ} \mathrm{C}\right) \\
& \alpha^{\prime}=6.111 \times 10^{-5}(1+v / 0.348)^{1 / 4} \theta_{s^{1 / 4}}
\end{aligned}
$$

となる.式(87)より，最高温度 $t_{\max }$ は，

$$
t_{\max }=Q / \alpha A
$$

式 $(90)^{\prime}$ より,

$$
\theta_{S}=\kappa\left(\gamma_{0}^{2} \nu_{0}\right)^{4 / 5}
$$

いまひずみ $\gamma_{0}$ ，周波数 $\nu_{0} \mathrm{~Hz}$ で測定したものを基準にと れば，任意の条件における表面温度は，

$$
\theta_{S}=\left(\frac{\gamma^{2} \nu}{\gamma_{0}^{2} \nu_{0}}\right)^{4 / 5}\left(\theta_{S}\right)_{0}
$$

で表わされる. 内部温度については, 時間 $\tau$ が充分大に なってサチレートし定常状態になると中心部と表面との 間には温度勾配をもつ。熱流が直線状であるとすれば, 熱伝達係数を $\kappa$, 伝熱面積を $A$, 中心から測定しようと
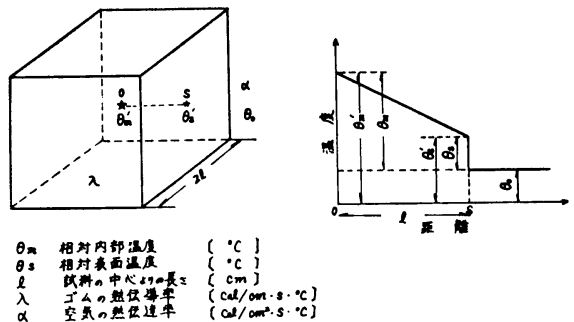

図39温度勾配と内部温度
する表面までの距離 $l$ との間には次式が成立する.

$$
\begin{aligned}
& 1 / \kappa A=1 / \alpha A+l / \lambda A \\
& \therefore \quad \kappa=\alpha \lambda /(\lambda+l \alpha)
\end{aligned}
$$

貫流熱量 $Q \kappa$ は，

$$
Q_{\kappa}=\kappa A\left(\theta_{m}{ }^{\prime}-\theta_{0}\right)
$$

伝熱抵抗 $R$ は,

$$
R=\kappa / \alpha=\lambda /(\lambda+l \alpha)
$$

表面温度 $\theta_{S}^{\prime}$ は,

$$
\theta_{s}{ }^{\prime}=\theta_{0}+R\left(\theta_{m}{ }^{\prime}-\theta_{0}\right)
$$

となるから，

$$
\theta_{m}=\theta_{s} / R=(\lambda+l \alpha) \theta_{S} / \lambda
$$

ただし，

$$
\begin{aligned}
& A ： \text { 伝熱面積 } \quad\left(\mathrm{cm}^{2}\right) \\
& l \text { : 表面迄の距離 } \quad(\mathrm{cm}) \\
& \alpha \text { : 空気の熱伝達率 } \quad\left(\mathrm{cal} / \mathrm{cm}^{2} \cdot \mathrm{s} \cdot{ }^{\circ} \mathrm{C}\right) \\
& \lambda: \text { ゴムの熱伝導率 } \quad\left(\mathrm{cal} / \mathrm{cm} \cdot \mathrm{s} \cdot{ }^{\circ} \mathrm{C}\right) \\
& \kappa \text { : 熱伝達係数 } \quad\left(\mathrm{cal} / \mathrm{cm}^{2} \cdot \mathrm{s} \cdot{ }^{\circ} \mathrm{G}\right) \\
& R: \text { 伝熱低抗 } \\
& \theta_{S}{ }^{\prime}: \text { 表面温度 } \\
& \theta_{m}{ }^{\prime}: \text { 内部温度 }
\end{aligned}
$$
$\alpha$ は式(90)'又は(91)'から求め得るから, ゴムの熱伝導 率入が解れば，表面温度を測定すれば, 式(99)より, 内 部温度が推定できるわけである。

図40は汎用防振ゴム材料のひずみの 2 乗と周波数との 積に対する相対表面温度の関係を示したものである．た だしひずみ $\gamma$ は圧縮方向に換算し周波数は $\mathrm{Hz}$ を単位に とってある. 図41は相対表面温度と相対内部温度の実測 值をプロットしたものである。これより NR, SBR, EP

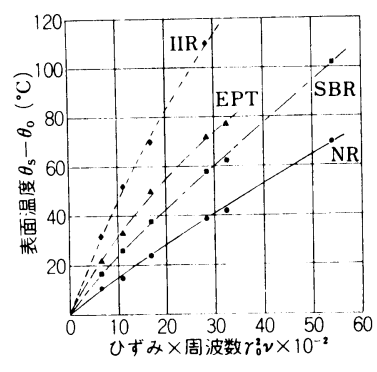

図40 各ポリマーの $\gamma_{0}{ }^{2 \nu}$ に対する表面温度

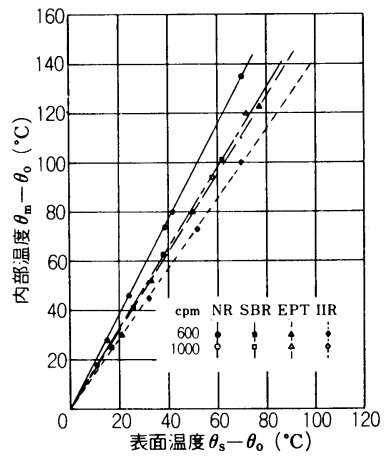

図41 各ポリマーの相対 表面及び内部温度

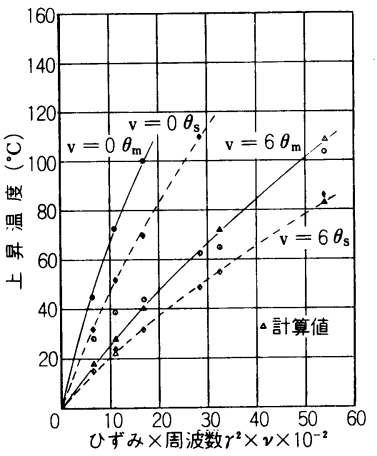

図42IIR に扩ける空冷の 効果 
表 3 各ポリマーの発熱実測值と計算值

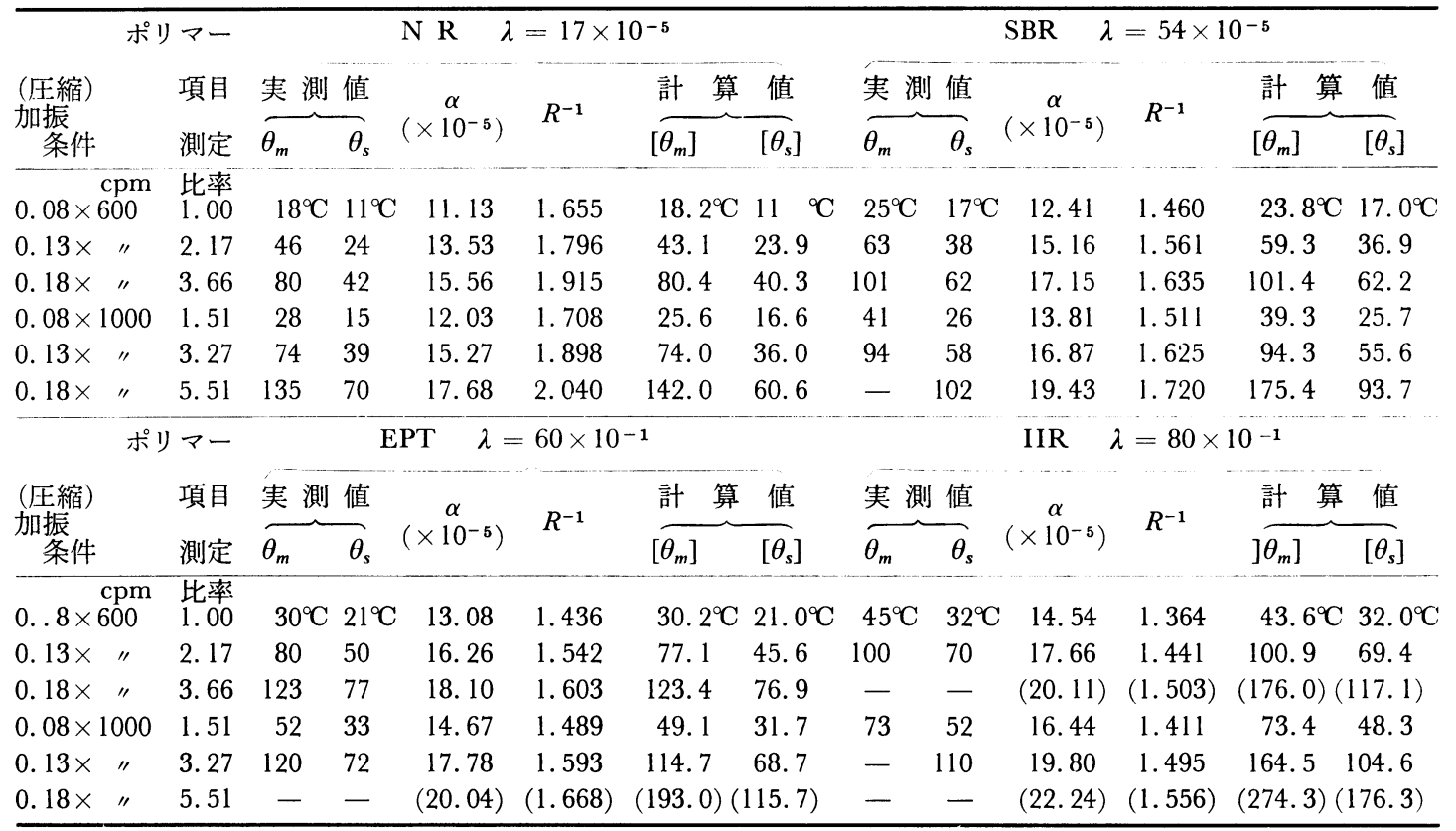

\section{一 測定不能 （）計算推定}

T, IIR 各ポリマーの入を求めると $17 \times 10^{-5}, 54 \times 10^{-5}$, $60 \times 10^{-5}, 80 \times 10^{-5}\left(\mathrm{cal} / \mathrm{cm} \cdot \mathrm{s} \cdot{ }^{\circ} \mathrm{G}\right)$ の值になり, $\theta_{S}$ は $\gamma=8 \%, \nu=10 \mathrm{~Hz}$ の条件による值を基準にとって式 (94)を用いて計算すれば表 3 に示すごとくよく一致す る.また $\theta_{s}$ と $\theta_{m}$ の関係は式(99)により，上記 $\lambda$ を用い て各条件による実例值と比較してある．更に IIR 及び SBR の試料については, $v=6 \mathrm{~m} / \mathrm{s}$ の空冷用空気を吹 きつけて測定した．空冷をした場合も式(94)は成立し， 式(91)' 及び (99)によって計算すれば表 4 に示すように なる. IIR の空冷の有無に対する実例値と計算值とを対 比すると図43のごとく割合よく一致している．以上の実 験結果より, 多少無茶な点もあるが, ゴム材料の熱伝導 率入がわかれば，表面温度を測定することによって，内 部最高温度が算出推定することが可能である.

\section{5 振動法と特性}

動的試験方法には，振動法と衝撃法とに大別され，振 動法は更に定常振動法，非定常振動法および自由減衰振 動法に区分される。波形には正弦波，三角波，短形波， ランダム波等種々あるが，通常防振ゴムの動的特性の測 定には，定常振動正弦波を用いている．特性の求め方に は，共振による共振倍率を求めて算出する方法と非共振 によってループを描き幾何図形的に算出する方法とがあ る.ダンピングの大きい材料の場合は, 共振曲線の山が
ダレるために共振法よりむし.ろ非共振によるループ図形 から求めるのがよい．ダンピングの小さい材料の場合に は，非共振によるループが直線状になり算出精度が低下 するので, 逆に共振法によるのがよい. 単にダンピング だけを求めたい場合には, 衝撃法であるリプケの反発弾 性測定のような簡単な測定法があり，振動法より求めら れる損失係数および自由減衰振動法より求められる対数 減衰係数との間には, 線型性が成立する範囲において は, 次式が成立する.

$$
\begin{aligned}
l & =-2 \ln \Delta / \sqrt{\pi^{2}+(\ln \Delta)^{2}} \\
& =-2 \ln (R / 100) / \sqrt{(2 \pi)^{2}}+\left\{\ln (R / 100)^{2}\right\}
\end{aligned}
$$

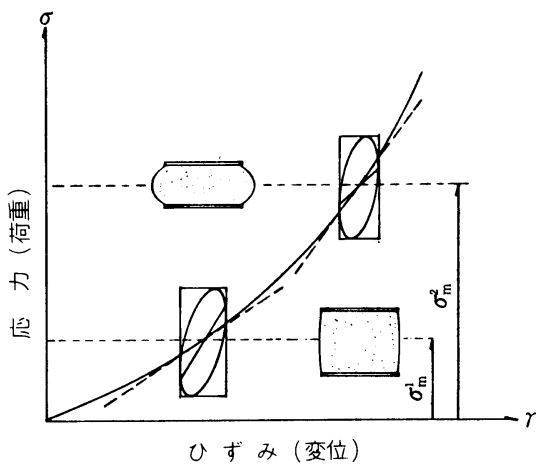

図43 初期応力の影響 
表 4 空気流通速度 $v=6 \mathrm{~m} / \mathrm{s}$ を吹きつけた場合の発熱

\begin{tabular}{|c|c|c|c|c|c|c|c|c|c|c|c|c|c|}
\hline \multirow{3}{*}{$\begin{array}{c}\text { (压縮) } \\
\text { 加搙 } \\
\text { 条件 }\end{array}$} & リマー & \multicolumn{6}{|c|}{ IIR } & \multicolumn{6}{|c|}{ SBR } \\
\hline & 項目 & 害 測 & 值 & & & 計 算 & 值 & 実 測 & 值 & $\alpha^{\prime}$ & $R^{-1}$ & 計 算 & \\
\hline & 測定 & $\theta_{m}$ & $\theta_{s}$ & $\left(\times 10^{-5}\right)$ & $n$ & {$\left[\theta_{m}\right]$} & {$\left[\theta_{s}\right]$} & $\theta_{m}$ & $\theta_{\mathrm{s}}$ & $0-5)$ & & {$\left[\theta_{m}\right]$} & {$\left[\theta_{s}\right]$} \\
\hline $0.08 \times 600$ & $\begin{array}{l}\text { 比率 } \\
1.00\end{array}$ & $28^{\circ} \mathrm{C}$ & $15^{\circ} \mathrm{C}$ & 7.673 & 1.192 & $17.9^{\circ} \mathrm{C}$ & $15.0^{\circ} \mathrm{C}$ & $16^{\circ} \mathrm{C}$ & $12^{\circ} \mathrm{C}$ & 7.042 & 1.261 & $15.1^{\circ} \mathrm{C}$ & $12.0^{\circ} \mathrm{C}$ \\
\hline $0.13 \times \quad "$ & 2. 17 & 44 & 32 & 9.821 & 1. 246 & 40.0 & 32.6 & & & & & & \\
\hline $0.18 \times \quad 1$ & 3.66 & 70 & 56 & 11.408 & 1.285 & 72.0 & 54.9 & & & & & & \\
\hline $0 . .8 \times 1000$ & 1.51 & 39 & 28 & 9.443 & 1. 236 & 34.6 & 22.6 & 28 & 18 & 8. 190 & 1.303 & 23.5 & 18.1 \\
\hline $0.13 \times \quad "$ & 3.27 & 63 & 48 & 10.970 & 1. 274 & 61.2 & 49.1 & & & & & & \\
\hline $0.18 \times$ & 5.51 & 104 & 86 & 12.622 & 1.316 & 113.2 & 82.7 & & & & & & \\
\hline
\end{tabular}

表 5 振動条件の特性への影響

\begin{tabular}{|c|c|c|c|c|c|}
\hline 条 件 & 特性値 & $\begin{array}{c}\text { 動 的 } \\
\text { 弹性率 } \\
\left(G_{1}\right)\end{array}$ & $\begin{array}{c}\text { 損失 } \\
\text { 弹性率 } \\
\left(G_{2}\right)\end{array}$ & $\begin{array}{c}\text { 損 失 } \\
\text { 你 } \\
(l) \text { 数 } \\
(l)\end{array}$ & 影響度 \\
\hline 周波数 v & の増大 & 増加 & 増加 & 変化 & 中 \\
\hline 振 幅 $x$ & 11 & 減少 & 变化 & 変化 & 大 \\
\hline 温 度 $T$ & $\prime \prime$ & 変化 & 変化 & 変化 & 大 \\
\hline $\begin{array}{l}\text { 平均 } \gamma_{m} \\
\text { ひずみ }\end{array}$ & $\prime \prime$ & 変化 & 変化 & 一定 & 中 \\
\hline 傾斜角 $\theta$ & $\prime \prime$ & 増加 & 増加 & 一定 & 大 \\
\hline
\end{tabular}

傾斜角 $\theta$ の増大はせん断から压縮方向を云う。

ただし，l は失損係数, $\ln \Delta$ は対数減衰係数， $R$ は反発 弾性率である.くわしくは動的試験方法を参照されたい. 実際防振支持する場合は, 加振体の重量が負荷され, そ の点で振動するわけである。したがって初期荷重による 影響を求めておくと便利であるが, 初期荷重を余り大き く与えると図 43 に示すごとく, 荷重一変位曲線の立上っ た領域(非線型領域) 点で試料も極度に変形し，バルジ (フクラミ)が大きくなり，形状効果が極度に影響するか ら注意を要する．変形方法はせん断変形が最も応力が均 一に負荷されるので精度がよい。

その他動的特性に及ぼす振動条件は, 前述の通り, 振 幅, 周波数, 温度がある. それらの影響をまとめると概 略表 5 に示すような傾向になるようである.

この依存性は材料別ごとに求めておく上設計上非常に 使利である。

\section{6. 振動耐久と疲労}

\section{1 ゴムの疲れの現象と特徵}

5.5 で示したようにIIRのごとくダンピングの大きい ポリマーは発熱が大きいために，萿ひずみではブローア ウトして測定できない場合がある。しかし空冷しながら 加振すると放熱が大きくなって内部温度が低下し破壊し ない.ゴムは熱, 酸素, 力学的刺激等の作用によって,
内部構造が著しく変化し, 物性が少化する. 更に進行す ると外力に耐えきれずにこわれる.これらの現象を総称 して“疲れ”という. 疲れのマク口的な現象としてはい ろいろな姿で現われる。熱や局部的刺激によって分子解 重合をしべタつく粘着現象, 初期の形状に永久に復元し ない変形現象 (ヘタリ), 物性が著しく劣化, 変化する変 質現象等のごとく材料の化学的物質に関する疲労現象や さらに, 局部的に分子切断するき裂現象, 外力に抗しき れずに分離切断する破断現象，接触する 2 つ境界面の 序耗現象等のごとく材料の機械的性質に関する破壊現象 がある。

力学的刺激による疲れは, ひずみ振幅によって左右さ れ，ひずみが大きいと前述のように発熱し疲労機構, 外 観的様相および内部構造が，発熱のない場合に比較し て，大きく異なる。一般に振動による疲れは，変形方向 にカーボン粒子が配列され，疎と密との部分に集団化 し，ゴム分子はその方向に結晶状になっているのが，電 子顕微鏡でみることができる.しかもこのカーボン及び ゴム分子の配列は非可逆的である．したがって損失係数 は減少し, 電気抵抗值は増加し, 平均体積膨潤率は減少 する．しかも方向によって膨潤率が異なる。一般基礎物 性では, 引裂強度が方向によって差異が生じ, 弾性率は 低下し, 引張強度, 伸びも低下減少するのが特徵であ る、熱による疲れ(純熱老化)は，架橋点がこわれ主鎖の 分子運動が活発になるので, カーボン分子は凝結して塊 状になるのが電子顕微鏡でみることができる．振動疲れ にみられるゴム分子の結晶化は発生しなく，損失倸数は 増大し, 電気抵抗值は余り変化せず, 平均体積膨潤率は 増加するのが大きな特徴である。一般基礎物性はいずれ む低下し，振動疲れと同一傾向にある，

酸化による疲れは, ポリマーの種類によって異なり, 酸化架橋するポリマーはモジュラスは増大し，NRのよ らに酸化によって分子切断するポリマーは，モジュラス 
は低下する．そしていずれも主鎖が切断されるのが特徴 である．したがって一般物性はすべて劣化低下する．通 常の老化試験では，熱老化と酸化が複合されているの で，両者の疲れ現象が生じることになる．

その他には破壊に影響する空洞生成によるダメージが ある、ゴムには種々の充填剂を混入するので, ゴム炭化 水素によく濡れない充填剤は，引伸変形を受けると界面 に離脱現象を起し空洞が生成されるのである。この空洞 はゴム内部の破壊核となり，特に振動に対しては応力集 中及び不均一応力の原因となってゴムの寿命を低下する ようである。

実際の使用の場合は上記要因が合成された形で作用し て疲れと云う現象となって現われるので，その再現性は 非常に難しいものがある. 破壊現象には 2 つ場合があ って，ゴムが疲労によって外力に抗しきれずにこわれる 場合と，ある大きな外力が加わり機械的に耐えきれずに こわれる場合である．前者を疲労破壊，後者を衝擊破壊 と呼んでいる。一般に経験的には, 疲労性の大なる材料 は破壊性にも劣るかというと必ずしもそうとはいえない ようである.むしろ実験結果では，ヘタリの大きい疲労 性の材料はこわれにくいが，物性変化の小さい耐疲労性 の材料が意外にこわれやすい傾向にある．すなわち疲労 性と破壊性とは本質的に相異するものと考えられる．高 温ふん囲気における耐久性のある材料は，低温耐久性に は劣り，逆に低温耐久に良好な材料が，高温においては 劣るので，耐久性に関する配合設計は最も難しい，特に
衝揧のごとくひずみ速度が相当に速い場合には，低温特 性が関係しより難しさがある。

\section{2 耐久曲線と寿命推定}

防振ゴムでは，振動特性と並んで振動耐久性は重要な 性質である。振動耐久のベンチテストの目的には，耐久 性の確認と寿命の推定および再現にある．耐久試験は相 当にバラッキが大きい，金属でも疲れのバラツキは $20 \%$ 〜30\%あるといわれている．振動耐久では特に破壊する までの繰返し数あるいは時間で表わしたときこれを寿命 (Fatigue Life) といい，破壊しない最大振幅を材料の疲れ 限度 (Fatigue Limit) 又は耐久限度 (Endurance Limit) と 呼んでいる。

ゴムの振動疲れ過程は，図44に示すごとく 3 段階に区 分される.第 1 段階は $10^{4}$ 回程度迄の初期に現われる現 象で，応力 $\sigma(\gamma)$ が急激に変化する期間である。主とし て充塡剤間およびゴム分子充填剂間の 2 次結合, 凝着力 の切断によるものと考えられる。この段階では，運転を 休止すればある程度疲労は回復するのが特徴である.

第 2 段階は $10^{4} \sim 10^{6}$ 程度の期間で, 応力 $\sigma(\gamma)$ の変化 が緩慢で，内部発熱温度がサチレートする．２次結合の 切断の進行と酸化による分子の架橋密度の変化が，だん だん促進し，破壊核の発生し始める期間である。したが ってゴム自体の物理的, 機械的性質が劣化するので, 運 転を休止しても回復はしない.

第 3 段階としては, $10^{6}$ 以上の期間で応力 $\sigma(\gamma)$ の変化 が再度起り，亀裂発生が目視され，外力に耐えきれずに

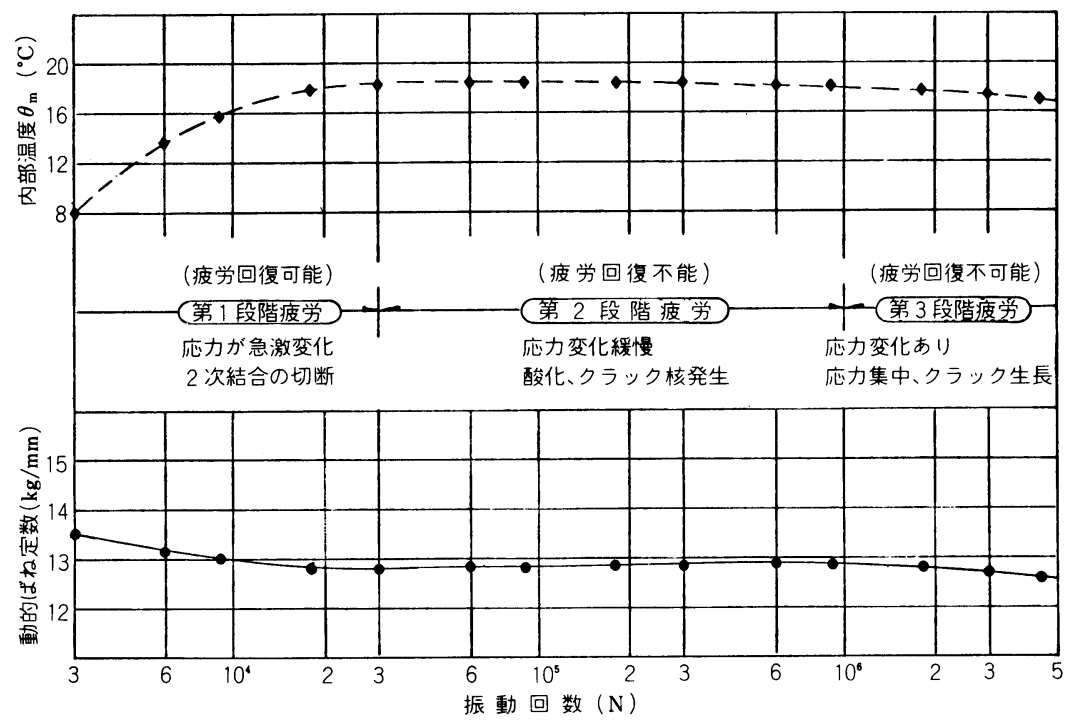

図44ゴム振動疲れ過程曲線 
破壊するか，極度の永久変形を起す期間である．

一般に耐久性のある材料の疲れ過程は, 第 2 段階の過 程期間が長い，したがって $5 \times 10^{6}$ まで異常がなければ， $10^{7}$ 回までは耐えられるようである。しかしこの疲れ過 程は, 振幅の大きさ, 周波数および温度によって左右さ れるので，各段階への移行が不明確の場合がある．振動 耐久試験で重要な点は， one point 試験によって耐久性 の判断をしてはならないことである．したがって少なく とも 3 points 以上の条件で試験し，金属のように S-N 曲線として現わすのが望ましいと考える．即ち苛酷な条 件で耐久性が満足したから，耐久性は充分保証し得ると 判断するのは危険である。その理由は配合のしかた及び ポリマーによっては，ひずみ振幅の大きい苛酷な条件で は耐え得るが，低ひずみ振幅ではそれほど耐久回数が伸 びない場合がある，一例をあげてみれば次のごとくであ る.

図45 はある乗用車の悪路走行 1 万 $\mathrm{km}$ における加振力

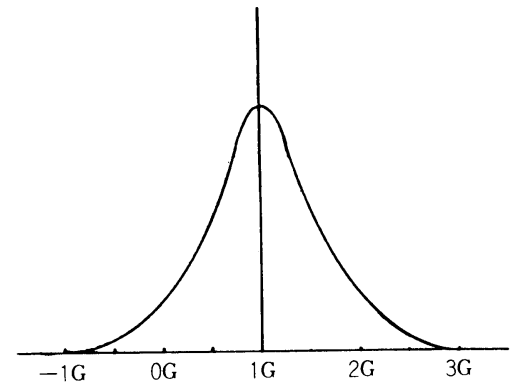

\begin{tabular}{|l|l|l|}
\hline 加振力 & 確率 & 覀路/万Km (回) \\
\hline $1 G \pm 2.0 G$ & 0.0026 & $6.0 \times 10^{4}$ \\
\hline. $\pm 1.5 G$ & 0.0218 & $4.9 \times 10^{5}$ \\
\hline. $\pm 1.0 G$ & 0.1092 & $2.46 \times 10^{6}$ \\
\hline $\pm 0.5 G$ & 0.8664 & $1.949 \times 10^{7}$ \\
\hline
\end{tabular}

汹45 実車走行の発生加振力分布困

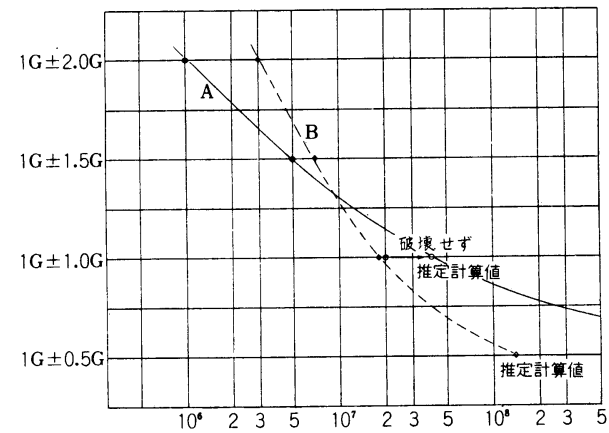

図46 加振力と $S-N$ 曲線

分布図と発生確率の一例であるが， $1 G$ に対して正規分 布を示し, 最大加振力はほぼ $2 G$ である. $1 G$ はエンジ ンによって異なる值であって，本例では $80 \mathrm{~kg}$ である. 図46は $1 G=80 \mathrm{~kg}$ の荷重で加振した場合の A, B 2 種 類の材料の耐久曲線である。 $\pm 2 G$ の苛酷な条件では確 かにB材料の方が優れている。しかし下記の寿命推定計 算方法で推定すれば表 6 のようになり，

$$
\begin{array}{ll}
\text { A 材料: } Z=4.316 \quad 4.316 \times 10^{4} \fallingdotseq 43,000 \mathrm{~km} \\
\text { B 材料: } Z=2.798 \quad 2.798 \times 10^{4} \fallingdotseq 28,000 \mathrm{~km}
\end{array}
$$

となる.（通常悪路走行 2 万 $\mathrm{km}$ は，一般走行の 10 万 $\mathrm{km}$ に相当するといわれている)推定寿命ではA材料の方が 1.5 倍程優れている. 実際この 2 種類の材料で試作した Engine Mounting の実車走行結果では, いずれも悪路 $25,000 \mathrm{~km}$ 走ったが，A材料は異状は認められず平均体 積膨潤率が約 $25 \%$ 小さい值を示した。しかしB材料はゴ ム中央部に $2 \mathrm{~mm}$ 程度の亀裂が発生していた。図47は 1 万 $\mathrm{km}$ 走行後の NR におけるカーボン種類による物性の 変化を示したもので，図中（）内は初期值を示し，膨 潤度はいずれも小さくなっているのが特徴である．寿命 推定計算は $n_{i}$ を使用発生確率回数とし， $N_{i}$ を耐久曲線 実測回数とすると，

$$
T=\sum n_{i} / N_{i}
$$

\begin{tabular}{|c|c|c|c|c|c|c|}
\hline \multirow[b]{2}{*}{ 加振力 } & \multicolumn{2}{|c|}{ 材料種類 } & \multicolumn{2}{|c|}{ A 材 料 } & \multicolumn{2}{|c|}{ B 材 料 } \\
\hline & 発生確率 $n_{i}$ & 実験 & $N_{l}$ & $n_{i} / N_{i}$ & $N_{i}$ & $n_{i} / N_{i}$ \\
\hline $1 \mathrm{G} \pm 2.0 \mathrm{G}$ & \multicolumn{2}{|c|}{$0.6 \times 10^{5}$} & $\times 10^{6}$ & 0.0600 & $\times 10^{6}$ & 0.0200 \\
\hline$" \pm 1.5 \mathrm{G}$ & \multicolumn{2}{|c|}{$4.9 \times 10^{5}$} & $\times 10^{6}$ & 0.0980 & $\times 10^{6}$ & 0.0700 \\
\hline$" \pm 1.0 \mathrm{G}$ & \multicolumn{2}{|c|}{$2.46 \times 10^{8}$} & $* 4 \times 10^{7}$ & 0.0615 & $2 \times 10^{7}$ & 0.1230 \\
\hline$" \pm 0.5 \mathrm{G}$ & \multicolumn{2}{|c|}{$1.95 \times 10^{7}$} & $* 1.6 \times 10^{9}$ & 0.0122 & $* 1.35 \times 10^{8}$ & 0.1444 \\
\hline \multicolumn{3}{|c|}{$\sum n_{i} / N_{i}=T$} & \multicolumn{2}{|c|}{$T_{A}=0.2317$} & \multicolumn{2}{|c|}{$T_{B}=0.3574$} \\
\hline
\end{tabular}

表 6 寿 命 推 定 計 算

* 印は推定計算による值である. 


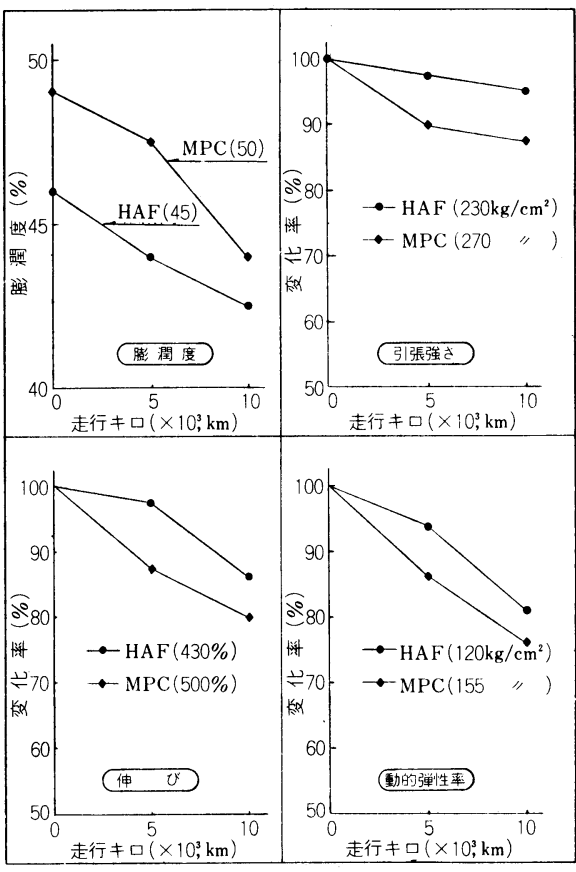

図47実車走行による物性の変化

$$
Z=1 / T
$$

で求められる。ここで $Z$ が寿命である.

\section{3 加振方法と振動耐久性}

ゴムの振動疲れ試験は, 配合によって弾性率が広範囲 に変るので，金属のように疲れ限度を応力で与えること は不都合である．したがって静的ひずみとひずみ振幅で 与える方が配合に無関係でほぼ一定に近い值が得られて 好都合である。図48(a)は, Engine Mounting Rear の応 力表示による図である。この図によれば IIR の方が耐 久性があるごとくに見えるが図(b)のようにひずみで表示 すれば，逆の結果になる。ゴムの場合はひずみで表示し た方がよい上いう一例である。

防振ゴムの疲れ試験には, 変位一定の条件のもとに行 与定変位式 (Constant deflection type) と荷重一定の条件 のもとに行う定荷重式 (Constant load type) の 2 つの加 振方法がある．現実の使用状況からみれば，定荷重式の 方が望ましいが，実験するには定変位式の方が便利さが ある，振動疲れ試験で注意しなければならないことは，

5.4 で述べたごとく，ひずみの 2 乗に比例し，さらに周 波数に比例して発熱するので，余り高ひずみ，高周波数 でしない方がよい，なぜならば疲れ試験か発熱試験がわ からなくなると同時に, 疲労形態も変化し, 真の振動疲 れおよび耐久性をみることができないことである。

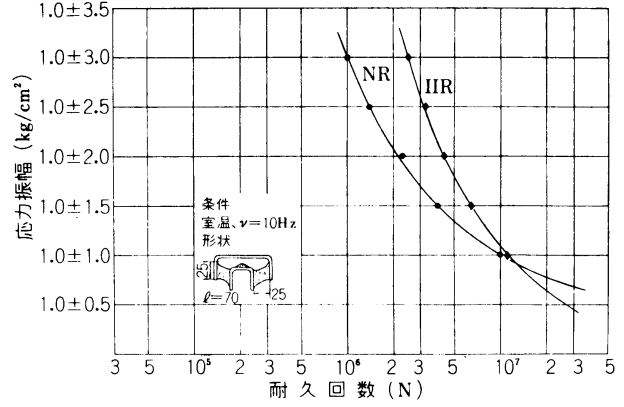

図48 (a) 定荷重せん断耐久曲線

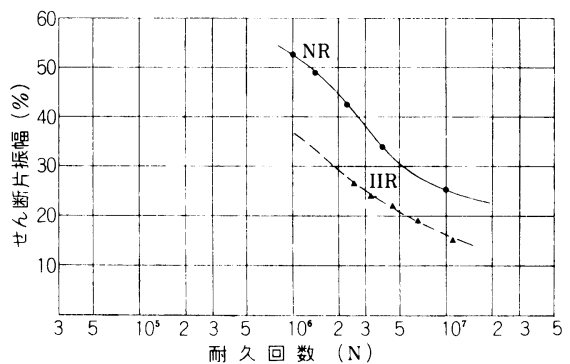

図48(b) 両振ひずみ振幅に変換

定荷重式と定変位式とによる振動耐久度は，弾性率の 减少率が大きい材料では，定荷重式で行らと寿命が短か く, 又もし増加変化するような材料では寿命は長くなる であろらと常識的に考えられる，通常は図49に示すよう に定変位式の場合は，振動疲れによってゴムの弾性率は 低下するので，荷重は減少し，また，定荷重式では変位 は増大する。いま初期の動的弾性率 (又は動的ばね定数) を $G_{0}$, 振動回数 $n$ 回後 (時闍表示では $t=n / \nu$ )の動的弾 性率を $G_{n}$ と表わし, 弾性率の変化が指数関数的に減少 すると仮定すれば，

$$
\begin{aligned}
& a_{n}=G_{0} e^{-a n} \\
& \kappa=a_{n} / a_{0}=e^{-a n}
\end{aligned}
$$

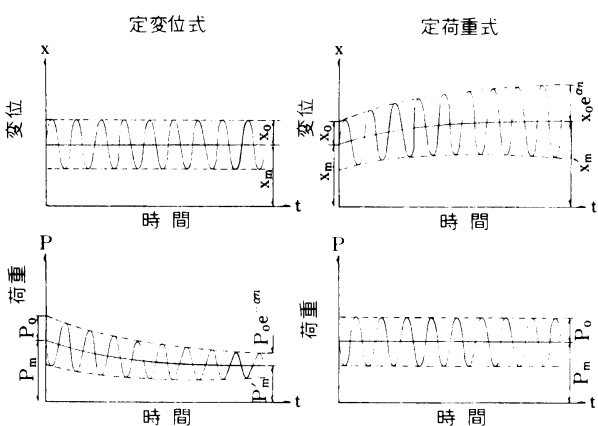

図49 定変位式と定荷重式 

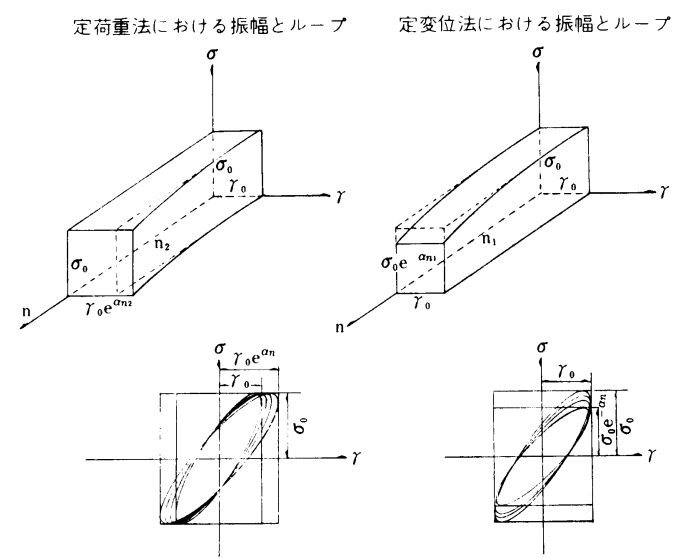

図50 定荷重式と定変位式における振幅とループ

$$
a=-\ln \kappa / n
$$

となる.ただし $a$ は材料, 形状および加振方法による係 数である．振動耐久性はゴムが外部に対してなす仕事量 に比例すると仮定して, 雨者の片振幅によるよる仕事量 を示せば図50ように考えられる。

定変位式では, $\gamma=\gamma_{0}=$ 一定, $\sigma=\gamma_{0} G_{0} e^{-a n}=\sigma_{0} e^{-a n}$ となるから $n_{1}$ 回で破壊したとすれば，全仕事量は，

$$
W_{\gamma}=\int_{0}^{n_{1}} \gamma_{0} \sigma_{0} e-a n d n=\gamma_{0} \sigma_{0}\left(1-e-a n_{1}\right) / a
$$

定荷重式では， $\sigma=\sigma_{0}=$ 一定, $\gamma=\sigma_{0} / G_{0} e^{-a n}=\gamma_{0} e^{a n}$ であるから $n_{2}$ 回で破壊したとすれば，

$$
W_{a}=\int_{0}^{n_{2}} \gamma_{0} \sigma_{0} e a n d n=\gamma_{0} \sigma_{0}\left(e a n_{2}-1\right) / a
$$

となる。したがって両者が等しくなる条件は，

$$
\left(1-e-a n_{1}\right)=\left(e a n_{2}-1\right)
$$

である．ここで $a$ が加振方法で変らないとすれば，定変

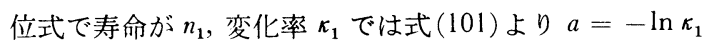
$/ n_{1}$ となるから, 式(108)は次のごとくなる.

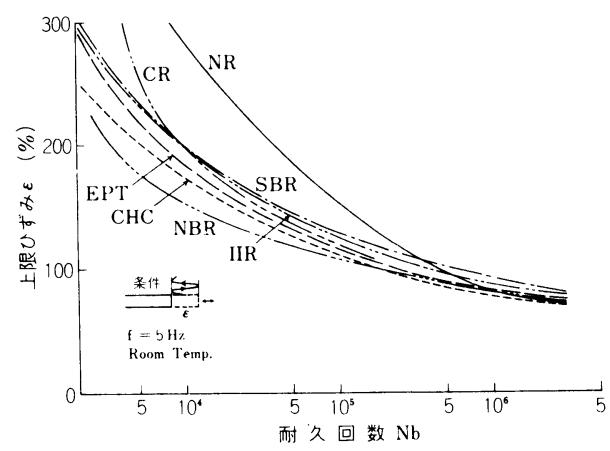

図51引張振動耐久 $1-\kappa_{1}=\kappa_{1}-n_{2} / n_{1}-1$

$1-\kappa_{1}=Z$ とおけば,

$$
\ln (1+Z)=-n_{2} / n_{1} \cdot \ln (1-Z)
$$$$
n_{2}=-n_{1} \ln (1+Z) / \ln (1-Z)
$$

$|Z|<1$ なるから式 (110) 右辺を展開し 3 乗以上の項を 省略すれば，

$$
\begin{aligned}
n_{2} & =(2-Z) /(2+Z) \cdot n_{1} \\
& =\left(1+\kappa_{1}\right) /\left(3-\kappa_{1}\right) \cdot n_{1}
\end{aligned}
$$

となり, 弾性率の大きく減少する材料は定荷重式の方が 寿命は短かくなる. もし $\kappa_{1}=1$ すなわち全然変化しな い場合のみ両者は全く一致しいずれの方法で試験しても 寿命は同じになることを意味している.

\section{4 変形方法と振動耐久性}

変形方法には, せん断, 圧縮, 引張り, 抳り, コジリ 変形等がある。ゴムにおいてはせん断変形が最も寿命は 長いことが知られている. 現実の使用状況では, せん断 または圧縮引張り，傾斜支持（せん断と圧縮引張りの複 合）による複合変形が多い，自動車の Engine Mount Front は殆んどすべてが傾斜複合変形で Rean はせん断 変形である。抳りやコジリ変形はBushing にみられる変 形で，特に捩りはせん断変形に類似している．製品によ る耐久試験では使用条件でするので種々の場 合がある が, 材料の疲労研究には, 短冊状試料による引張変形で 行う場合がある. 図 51,52 , 及び 53 はその一例であ る.

振動耐久性は変形方法によって異なるために，一定の 振動条件においてのみしか比較できないので設計上非常 に不便である．防振ゴムの使用上からすれば，せん断， 圧縮，および傾斜による複合変形を与える場合が多いの で両者について考えてみる. せん断変形と圧縮変形それ ぞれの仕事量を計算してみると，

圧縮引張については，
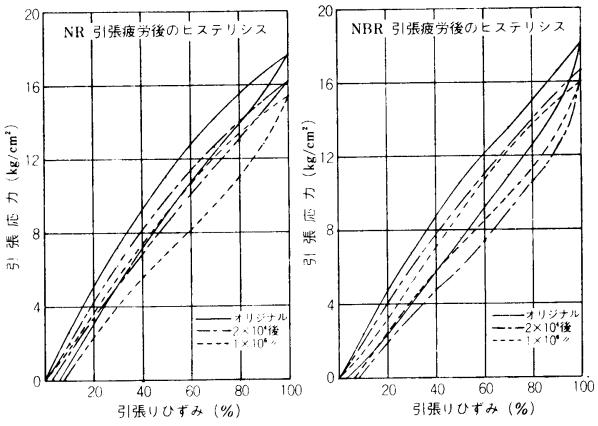

図52 NR 及び SBR の引張痩労後のヒステ リシス 


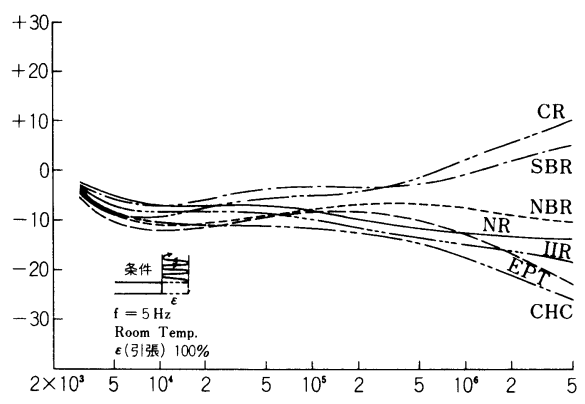

図53 引張疲労過程曲線

$W_{C}=\int_{0}^{\varepsilon} \sigma d \varepsilon=\int_{0}^{\varepsilon} G\left\{(1+\varepsilon)-(1+\varepsilon)^{-2}\right\} d \varepsilon \fallingdotseq 3 G \varepsilon^{2} / 2$

せん断については,

$$
W_{S}=\int_{0}^{\gamma} \tau d \gamma=\int_{0}^{\gamma} G \gamma d \gamma=G \gamma^{2} / 2
$$

となるから，両変形の寿命が等価であるためには， $W_{\boldsymbol{C}}$ と $W_{S}$ が等しいと仮定すれば，

$$
\gamma=\sqrt{3} \varepsilon
$$

となり, せん断変形では圧縮の約 2 倍のひずみ量に耐え 得ることになる.この関係は実際の実験からもいえるよ らである. 傾斜による複合変形は, せん断と圧縮の両変 形が合成されたもので，金属における曲げと㨝りの疲れ 限度理論を応用し得る.したがってせん断と圧縮の複合 関係は図54に示すように棈円になる．縦軸 $y$ 方向に圧縮 ひずみをとり，横軸 $x$ 方向にせん断ひずみをとれば，

$$
x^{2} / \gamma^{2}+y^{2} / \varepsilon^{2}=1
$$

と表わし得る．いま任意の傾斜角を $\theta$ とすれば，その時 のひずみ振幅は原点から点 $p$ 迄の長さ $\gamma_{\theta}$ になるから， 点 $p$ の座標を $\left(x_{0}, y_{0}\right)$ とすると，

$$
\begin{aligned}
& y_{0}=r_{\theta} \cos \theta \quad x_{0}=r_{\theta} \sin \theta \\
& x_{0}^{2} / \gamma^{2}+y_{0}^{2} / \varepsilon^{2}=1
\end{aligned}
$$

となる. 式(116)の $x_{0}, y_{0}$ を消去すれば，
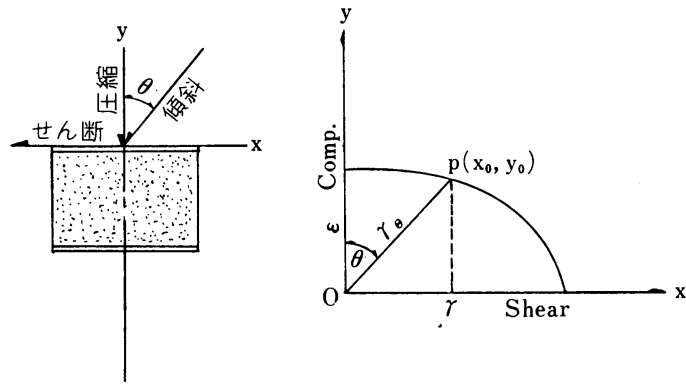

図54 変形様式関係図
表 7 せん断ひずみ振巾 $25 \%$ に対する各傾斜の対応 ひずみ振幅

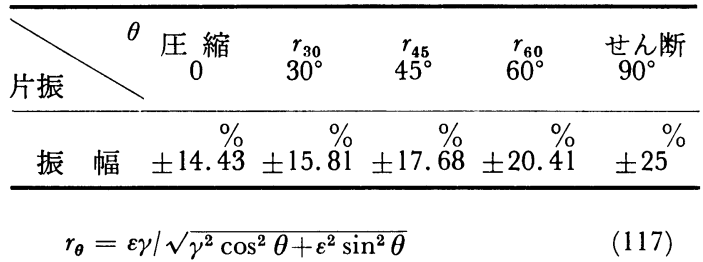

更に式(114)より，

圧縮変形基準では

$$
r_{\theta}=\sqrt{3} \varepsilon / \sqrt{2 \cos ^{2} \theta+1}
$$

せん断変形基準では

$$
r_{\theta}=\gamma / \sqrt{2 \cos ^{2} \theta+1}
$$

と表わし得る. 上式を用いてせん断変形における. $\gamma=$ $\pm 25 \%$ と同等の寿命を期待し得る各傾斜角及び圧縮変 形のひずみ振幅を求めてみると表 7 に示すようになる. 図 55 のごとき試料を用い, $\theta=0$ 圧縮， $\theta=45^{\circ}$ 傾斜， $\theta=90^{\circ}$ せん断の各変形による両振振動モードでの耐久 性は図 56 に示すようになり，このひずみ振幅を式(119) せん断基準に変換すれば，図56のせん断による耐久線上

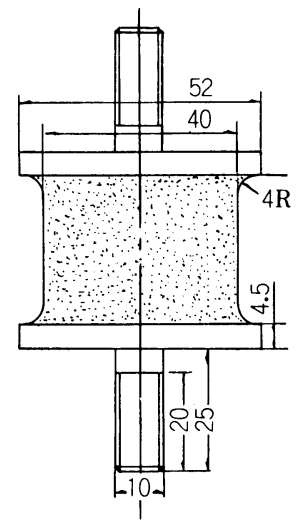

図55 耐久試験用試料（角柱型）

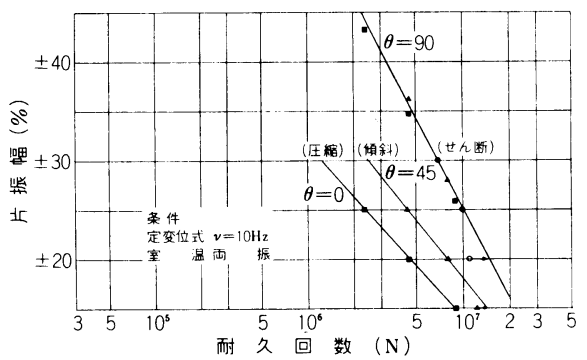

図56 両振における圧縮, 傾斜複合及びせん断の比 較と変換 


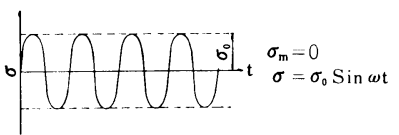

両振

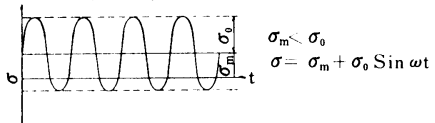

部分両振

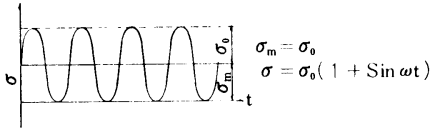

片振

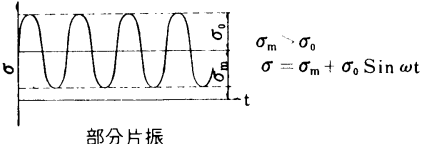

部分片振

図57 振動モード $a_{m}$ と $\sigma_{0}$ との関係

にのるようである. すなわち種々の傾斜角での振動耐久 結果を任意の傾斜角に置換え比較し得ることを証明して いる。

\section{5 振動モードと振動耐久性}

試料を加振する振動モードには, 図57に示すようにい ろいろの場合がある. いま最大応力を $\sigma_{2}$, 最小応力を $\sigma_{1}$ とすれば,

$$
\begin{array}{ll}
\sigma_{2}-\sigma_{1}=2 \sigma_{0} & \text { 全振幅 } \\
\left(\sigma_{2}-\sigma_{1}\right) / 2=\sigma_{0} & \text { 片振幅または応力振幅 } \\
\left(\sigma_{2}+\sigma_{1}\right) / 2=\sigma_{m} & \text { 平均応力 }
\end{array}
$$

とそれぞれいい，平均応力が $\sigma_{m}=0$ の場合を特に両振 (Complete reversed) と呼び， $\sigma_{m}=\sigma_{0}$ の場合を片振 (Plusating)と呼んでいる.

$$
\begin{array}{lll}
\sigma_{m}=0 & \sigma=\sigma_{0} \sin \omega t & \text { 両 振 } \\
\sigma_{m}<\sigma_{0} & \sigma=\sigma_{m}+\sigma_{0} \sin \omega t & \text { 部分両振 } \\
\sigma_{m}=\sigma_{0} & \sigma=\sigma(1+\sin \omega t) & \text { 片r振 } \\
\mathrm{o}_{m}>\sigma_{0} & \sigma=\sigma_{m}+\sigma_{0} \sin \omega t & \text { 部分片振 }
\end{array}
$$

ひずみ振幅の場合は，応力をひずみに代えれば，全く 同じ呼称でよい，実際の防振支持状態では，被支持体の 荷重が負荷されその点を基蕉に振動するから， $\sigma_{m}>\sigma_{0}$ の部分片振の場合が多い. 平均応力 $\sigma_{m}$ または平均ひず み $\gamma_{m}$ は振動耐久性に影響し, 通常は大きくなれば耐久 性は減少するはずである。この $\sigma_{m}$ または $\gamma_{m}$ と振幅と の関係は図58に示すよらになる。

$\mathrm{Y}$ 軸に振幅をとり $\mathrm{X}$ 軸に平均ひずみをとれば， $\mathrm{XY}$ 軸 と角度 $45^{\circ}$ の直線は任意の平均ひずみを表わす．点Qは 金属の場合には降伏点であるが，ゴムの場合では降伏点 が明確に現われないために，両振と片振による耐久等価 振幅を求める必要がある. $\mathrm{Y}$ 軸上に両振の片振幅 $\overline{\mathrm{OC}}$ を

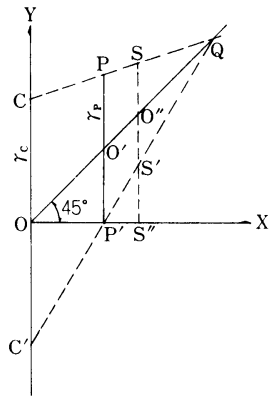

図58 平均ひずみ(応力)と振幅の関係

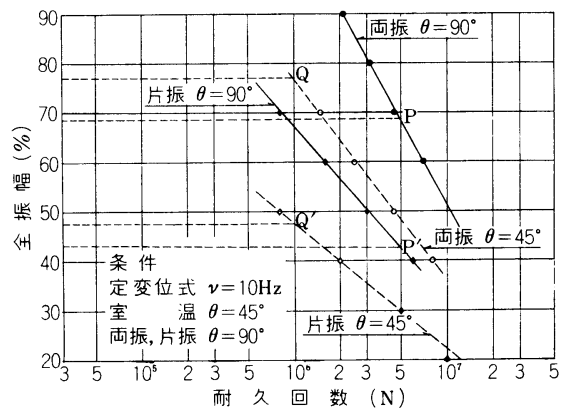

図59両振と片振による耐久曲線

とり， $\mathrm{X}$ 軸上に片振の片振幅 $\overline{\mathrm{OP}}^{\prime}$ をとって点 $\mathrm{P}^{\prime}$ に垂線 を引き $45^{\circ}$ の直線との交点を $\mathrm{O}^{\prime}$ とし $\overline{\mathrm{P}^{\prime} \mathrm{O}^{\prime}}=\overline{\mathrm{O}^{\prime} \mathrm{P}}$ なる 点 $\mathrm{P}$ と点 $\mathrm{G}$ を結び $\overline{\mathrm{OO}}^{\prime}$ 線との交点が $\mathrm{Q}$ になる．この $\overline{\mathrm{CQ}}$ は振幅限界線を表わし, $\overline{\mathrm{OC}}=\overline{\mathrm{OC}^{\prime}}$ なる点 $\mathrm{C}^{\prime}$ とQ 点を結べば必ず $\mathrm{P}^{\prime}$ 点を通り $\overline{\mathrm{C}^{\prime} \mathrm{O}}$ が限界全振幅を表わす ことになる。

せん断及び傾斜角 $45^{\circ}$ の 2 種の変形方法による両振と 片振の耐久曲線は図59のごとくなった．この曲線図より 各耐久回数に等価になる全振幅を求め, 両者の振幅比を 算出すれば，表 8 のよ5になり，ほぼ $\gamma_{C} / \gamma_{P}=1.6$ とな った. 即ち両振は片振幅の 1.6 倍のひずみ振幅で耐久的 に等価になることを示している.

次に任意の平均ひずみ $\gamma_{m}$ が与えられている場合のこ れに等価な両振振巾を求める一般式を求めてみる. C 点 の座標は $\left(0, \gamma_{C}\right), \mathrm{P}$ 点の座標は $\left(\gamma_{P}, 2 \gamma_{P}\right)$ なるから, $\overline{\mathrm{CQ}}$ の直線の方程式は，

$$
Y=\left(2 \gamma_{P}-\gamma_{C}\right) / \gamma_{P} \cdot X+\gamma_{C}
$$

しかるに $\gamma_{C}=1.6 \gamma_{P}$ なるから，

$$
Y=0.4 X+\gamma_{C}
$$

となる. 一方平均ひずみの方程式は方向余弦は 1 である から， $Y=X$ である. 、ま任意の平均ひずみが $\gamma_{m}$ であ るから， 
表 8 両振及び片振の耐久等価振幅

\begin{tabular}{|c|c|c|c|c|c|c|c|}
\hline \multirow[b]{2}{*}{ 耐久回数 } & \multirow{2}{*}{$\begin{array}{l}\text { 変形様式 } \\
\text { 振動様式 }\end{array}$} & \multicolumn{3}{|c|}{ せん断変形 $\quad\left(\theta=90^{\circ}\right)$} & \multicolumn{3}{|c|}{ 傾斜 変形 $\left(\theta=45^{\circ}\right)$} \\
\hline & & 片振全振巾 & 両振全振巾 & \multirow{2}{*}{$\frac{\text { 振巾比 } \gamma_{p} / \gamma_{c}}{1.596}$} & 片振全振巾 & \multirow{2}{*}{$\begin{array}{r}\text { 両振全振巾 } \\
64.5 \%\end{array}$} & \multirow{2}{*}{$\frac{\text { 振巾比 } \gamma_{p} / \gamma_{c}}{1.612}$} \\
\hline & $10^{6}$ 回 & $57 \%$ & $91 \%$ & & $40 \%$ & & \\
\hline 3 & " " & 50 & 81 & 1.620 & $35.5 \prime$ & $57 \quad$ & 1.606 \\
\hline 4 & " & 46 & $74 \prime \prime$ & 1.608 & $32.5 "$ & $52 \prime \prime$ & 1.600 \\
\hline 5 & $" \prime$ & 43 & $68.5 "$ & 1.593 & $30 \prime$ & $48.5 \prime \prime$ & 1.617 \\
\hline 6 & " & $40 "$ & $64 \prime$ & 1.600 & 28 & $45 \prime \prime$ & 1.607 \\
\hline 7 & $" 1$ & $37.5 "$ & 60 & 1.600 & 26 & 42 & 1.615 \\
\hline 期 & 待 值 & & & 1.6 & & & 1.6 \\
\hline
\end{tabular}

$$
\begin{aligned}
& Y_{1}=0.4 \gamma_{m}+\gamma_{C} \\
& Y_{2}=\gamma_{m}
\end{aligned}
$$

とおけば，ひずみ振幅 $\gamma$ は，

$$
\begin{gathered}
\gamma=Y_{1}-Y_{2}=-0.6 \gamma_{m}+\gamma_{c} \\
\therefore \gamma_{c}=\gamma+0.6 \gamma_{m}
\end{gathered}
$$

となる. 即ち平均ひずみ $\gamma_{m}$ が与えられている場合, ひ ずみ振幅 $\gamma$ なる部分片振または部分両振は, 式 (125)に よって耐久等価の両振振幅に変換し得ることを示してい る. 金属では両振による振動耐久を基準にしているよう であるが，ゴムの場合は種々の方法で行っており一定し ていないようである。

しかし防振ゴムの文献によれば，最小ひずみが零にな るような片振が寿命の最小になることが述べられてい る.せん断変形によるその一例を示せば，

$\begin{array}{rlrr}0 \pm 25 \% & \text { 両 振 } & 7 \times 10^{6} \\ 25 \% \pm 25 \% & \text { 片 } & \text { 振 } & 1 \times 10^{6} \\ 100 \% \pm 25 \% & \text { 部分片振 } & 15 \times 10^{6}\end{array}$

上記の結果例における両振と片振については, 理解さ れるが部分片振が両振の約 2 倍の耐久性がある点につい ては説明ができない. せん断変形, 引張変形ではこうし た現象がみられるようであるが，圧縮変形あるいは傾斜 複合変形においては，平均ひずみを大きくすれば寿命は 低下する.ただし加振方向に対し直角方向にプレコンプ

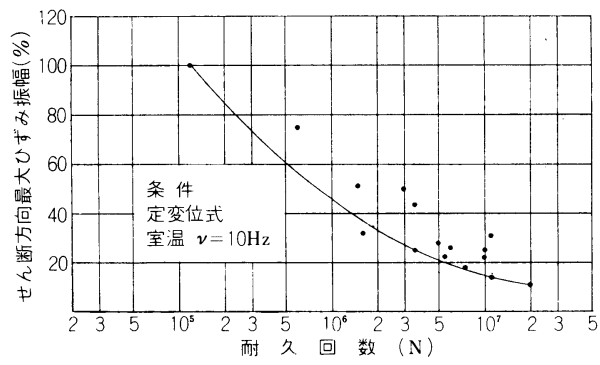

図60 せん断方向最大ひずみ表示による耐久曲線
レッションあるいはプレテンションを与えた場合は, 寿 命は伸びる現象がある．これらの現象については，今後 の研究をまちたい.

\section{6 振動耐久に対する雑感}

振動耐久性の試験, 実験は一般物性試験に比較して相 当に長時間かかることである. 種々の要因を考え， 3 水 準 $L_{27}\left(3^{4}\right)$ の直交配列法による実験計画をうまく使って も, 繰返し数 $n=3$ 程度で平均耐久回数 $8 \times 10^{6}$ とすれ ば, 周波数 $\nu=10 \mathrm{~Hz}$ では 1 台の振動耐久試験機で, 何 んと尽夜フル運転して 2 年余もかかる。したがって当然 同一ロットでの試料による試験は不可能になる. 通常ゴ ムの振動耐久試験は，応力が割合均一に負荷し得る点か らせん断変形によることが多いが，しかし現実の使用状 況では, 圧縮あり，傾斜支持による複合変形あり，しか もその傾斜角がいろいろであって寿命の推定は非常に困 難である.

更に耐久試験は上述のように相当に長時間かかるの で，簡単に求められないので，マクロ的でいいから条件 の異なる耐久データが利用できないかどうか考えたの が，合まで述べてきた耐久条件の変換理論である．表 9 は材質 NR の製品で種々の条件によって耐久試験をし た結果の一例である. 従来は比較するためにせん断方向 あるいは圧縮方向への最大ひ与゙み振幅に変換したが，図

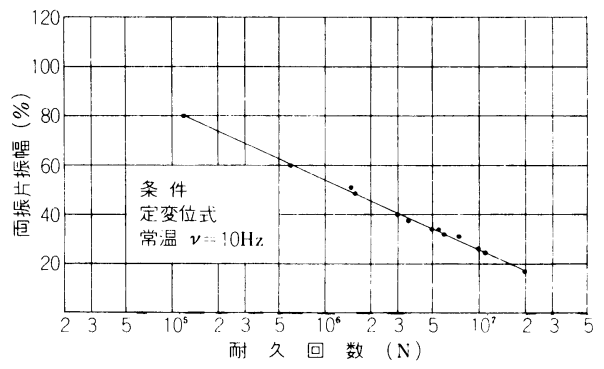

図61 変換理論による耐久曲線 
司

表 9 製品による耐久性

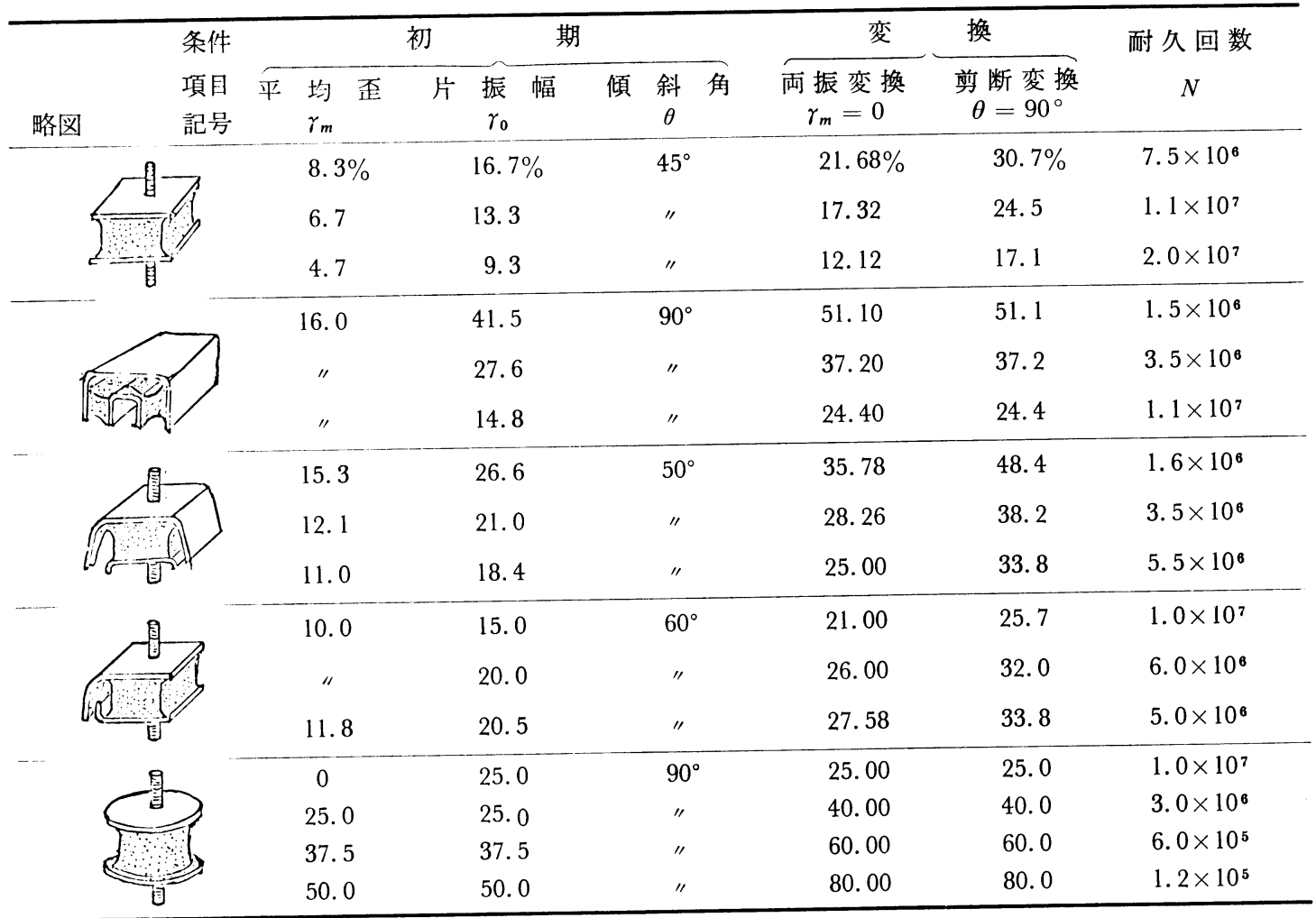
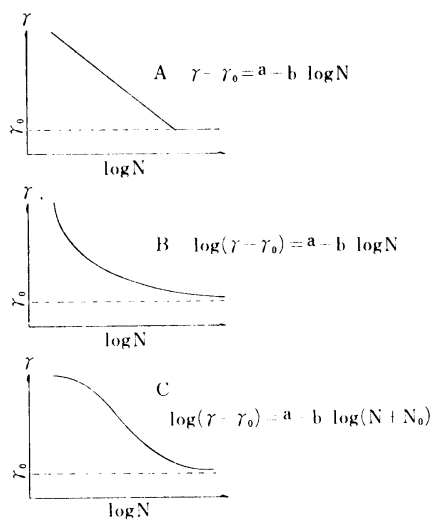

図62 耐久 $S-N$ 曲線の種類

60に示すように相当にバラツキうまく利用できない。し かし同データを式(125) 及び(119)を用いて，せん断両振 振幅に変換して表わせば図61に示すように，一直線上に のり $S-N$ 曲線として使用し得る姿になる。

ゴムに㧍ける $S-N$ 曲線では，金属にみられるような 疲れ限度は明確には現われないが，低温での耐久実験で

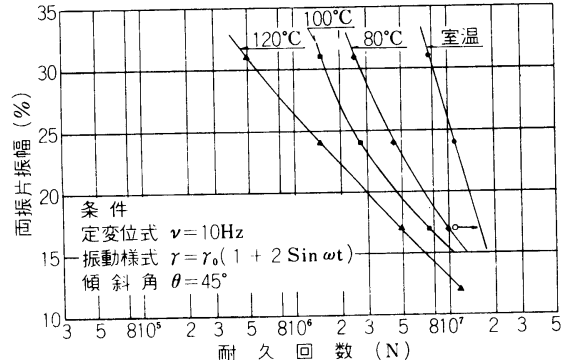

図63 NR の高温ふん囲気における耐久曲線

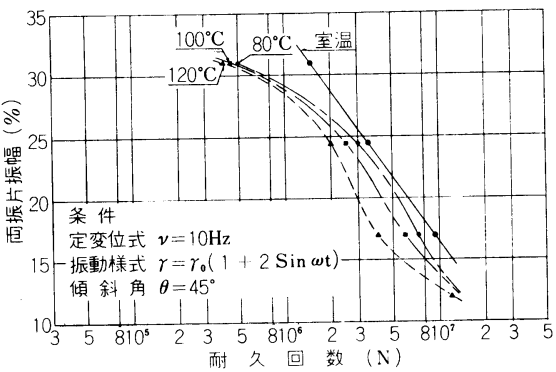

図64 IIR の高温ふん用気における耐久曲線 
は出現するようである．また $S-N$ 曲線の種類は図 62 に 示すように大体 3 種類に分類できそうである.

通常定変位式ではAタイプになり，定荷重式ではB夕
イプになる．しかし定変位式でも高温雲囲気中では，図 63に示すごとく B タイプになり，ダンピングの大きいII $\mathrm{R}$ では図 64 に示すような C タイプの $S-N$ 曲線になる.

\section{H901140}

\section{新時代のバスを作る進歩した材料と方法}

Materials, processes usher new transit era

米国の GM 社の Truck \& Coach Div. は，1976年中 頃に全く新しい設計による大形バスの製造を開始する予 定である.

材料は，強さおよび耐食性が優れたものを使する。す なわち, 車体と天井は, 極めて強くて耐食性のあるク口 ムとチタンを加えて安定したステンレス鋼である．下部 構造は，高力低合金鋼で作り，しかも液体ワックスを満 たした $50 \mathrm{ft}$ の長さの浴に沈めて耐食性を増す処理を施 す．ボルト，ナットなども耐食処理を施したものを使用 する. サイドパネルは染料を含浸させたアクリル 樹脂 で，強くて耐食性が強く，へこまず，きずが付かない. このパネルは洗いやすく，取替えが簡単にできる．空に は従来のガラスの10倍の衝撃に耐える厚さ $1 / 2 \mathrm{in} の$ 硬い被 覆を施したアクリル樹脂板を張る.

バスは乗客の乗心地がよいように工夫してある．座席 は片持ばり方式で側壁に取付けてあるため足が自由に動 かせる．温度制御は完全自動である．車内灯はけい光灯 である，また，乗心地がよく操縦が楽であるように車体 の支持を空気ばねにしている.
バスの製造方法は，極めて進歩したもので，溶接を多 用している。モジュールを製作し，車体を組立てるに使 用する装置の多くは，計算機制御を受ける，車体は全長 $40 \mathrm{ft}$ であるが, 各 $5 \mathrm{ft}$ のモジュール 8 個を溶接して作る. 従来のバスに比しリベットの量は大幅に減ぜられる.モ ジュールを溶接する装置は Resistance Welder 社，車体 溶接ラインは Newcor 社の受持である.

Resistance 社のモジュール製作ラインは角形のメリー ゴーラウンド型で，12台の台車がいくつかの製作ステー ションを通過している間にモジュールを作る．各台車は 圧縮空気作動方式と空気タンクを備え，36個の部品を溶 接ステーションで点溶接と抵抗溶接によって接合する.

Newcor 社の車体溶接ラインは, 装荷, 移動および 5 台の溶接ステーションからなり，前後部と 6 個の中間部 のモジュールを接合する.この溶接は14台のアーク溶接 機によって同時に行ない，クランプした状態で冷却す る.トーチは，保持往復台上で自動案内方式により移動 する.アーク溶接中に 3 台の抵抗溶接機が上下のクロス 部品を溶接する．溶接品質は，㷌還制御方式によって制 御する. 写図 4

OBRZUT J J

C209A Iron Age 216 [17] 63-55 ('75)〔日本科学技術情報 センター発行「海外技術ハイライト」より転載許可第165号] 